University of Louisville ThinkIR: The University of Louisville's Institutional Repository

Electronic Theses and Dissertations

$5-2019$

\title{
Exploring the Indian opinion : interpretations of colonialism, anti-colonial activism, and Gandhi's influence in three African countries, 1950-1960.
}

Alexander Ganesha Kaliannan

University of Louisville

Follow this and additional works at: https://ir.library.louisville.edu/etd

Part of the Africana Studies Commons

\section{Recommended Citation}

Kaliannan, Alexander Ganesha, "Exploring the Indian opinion : interpretations of colonialism, anti-colonial activism, and Gandhi's influence in three African countries, 1950-1960." (2019). Electronic Theses and Dissertations. Paper 3173.

https://doi.org/10.18297/etd/3173

This Master's Thesis is brought to you for free and open access by ThinkIR: The University of Louisville's Institutional Repository. It has been accepted for inclusion in Electronic Theses and Dissertations by an authorized administrator of ThinkIR: The University of Louisville's Institutional Repository. This title appears here courtesy of the author, who has retained all other copyrights. For more information, please contact thinkir@louisville.edu. 
EXPLORING THE INDIAN OPINION: INTERPRETATIONS OF COLONIALISM, ANTI-COLONIAL ACTIVISM, AND GANDHI'S INFLUENCE IN THREE AFRICAN COUNTRIES, 1950-1960

\author{
By \\ Alexander Ganesha Kaliannan \\ B.A., Loyola Marymount University, 2017
}

A Thesis

Submitted to the Faculty of the

College of Arts and Sciences of the

University of Louisville

In Partial Fulfillment of the Requirements

for the Degree of

Masters of Arts in Pan-African Studies

Department of Pan-African Studies

University of Louisville

Louisville, Kentucky

May 2019 

EXPLORING THE INDIAN OPINION: INTERPRETATIONS OF COLONIALISM, ANTI-COLONIAL ACTIVISM, AND GANDHI'S INFLUENCE IN THREE AFRICAN COUNTRIES, 1950-1960

\author{
By \\ Alexander Ganesha Kaliannan \\ B.A., Loyola Marymount University, 2017
}

A Thesis Approved on

April 22, 2019

By the following Thesis Committee:

Dr. Theresa Rajack-Talley

Dr. Tyler Fleming

Dr. Mawuena Logan 


\section{ACKNOWLEDGMENTS}

I would like to thank my family for giving me the opportunity to pursue higher education and supporting me in achieving my dreams. Also, I would like to thank Dr. Tyler Fleming and Dr. Rajack-Talley for their invaluable guidance in the crafting of this

thesis. Finally, I would like to thank my mentor, Dr. Dexter Blackman, for his support, advice, and inspiration throughout my career. 


\begin{abstract}
EXPLORING THE INDIAN OPINION: INTERPRETATIONS OF COLONIALISM, ANTI-COLONIAL ACTIVISM, AND GANDHI'S INFLUENCE IN THREE AFRICAN

COUNTRIES, 1950-1960

Alexander Ganesha Kaliannan

April 22, 2019

My research began by uncovering connections between the Non-Cooperation movement in India, led by Mohandas Gandhi and the Pan-Africanist movement in Ghana, led by Kwame Nkrumah, illuminating the process in which Nkrumah engaged with Gandhi's political non-violence and non-cooperation. The research then sought to understand how the Mau Mau uprising acted as anti-colonial activism in Kenya, and how the Indian diaspora in both South Africa and Kenya, were interpreting the colonial response to the Mau Mau. This thesis aims to answer two questions: How did Gandhi's political philosophies of non-violence influence/inform leaders, activists, and movements in Kenya and Ghana during the 20th century, and did diasporic interactions between Africans and Indians in the Global South yield a shared anti-colonial identity in resistance to British colonial rule? In answering these questions, this study identifies in what ways satyagraha impacted the anti-colonial activisms of Indians and Africans in colonial Kenya and Ghana and describes the negotiating of South Africa Indian views on violent and non-violent resistance to colonialism.
\end{abstract}




\section{TABLE OF CONTENTS}

ACKNOWLEDGMENTS $\ldots \ldots \ldots \ldots \ldots \ldots \ldots \ldots \ldots \ldots \ldots \ldots \ldots \ldots \ldots \ldots \ldots \ldots \ldots \ldots \ldots \ldots \ldots \ldots \ldots$ ii

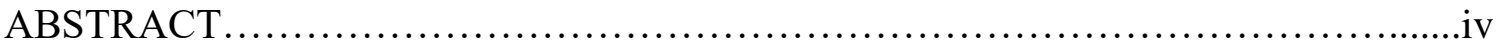

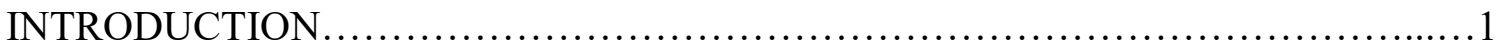

Gandhi: The Man......................................................

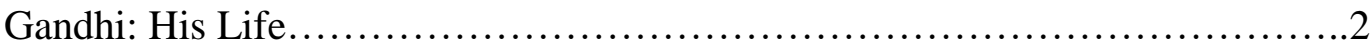

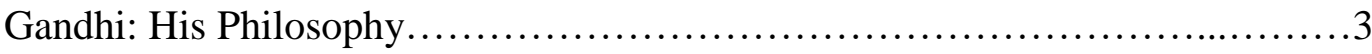

Gandhi’s Influence in South Africa............................................8

South Africa and India................................................... 12

Indian Opinion........................................................ 15

Methods.............................................................. 17

INTERPRETATIONS OF ANTI-COLONIAL ACTIVISM IN KENYA..............21

Background to Kenya's Movement of Colonial Resistance...................21

Perspectives on the Social Context of the Mau-Mau..........................28

S.A. Indian's perception of the Mau-Mau............................. 40

S.A. Indian's perception of the Colonial Response to the Movement...........47

Gandhi's Influence on the Movement and leader(s) of Movement...............53

INTERPRETATIONS OF ANTI-COLONIAL ACTIVISM IN GHANA $\ldots \ldots \ldots \ldots \ldots . . .56$

Background to Ghana's Independence Movement............................56

Perspectives on Social Context of Ghana's Independence Movement...........62

S.A. Indian's perception of the Movement (Ghanaian Independence)...........66 
S.A. Indian's perception of the Colonial Response to the Movement.

Gandhi's Influence on the Movement and leader(s) of Movement...............72

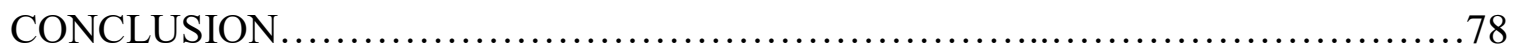

Discussion and Analysis........................................... 78

Summary and Findings: The Role of Gender and Race....................82

Perceptions of Violence and Non-Violence in the Mau Mau and the Ghanaian

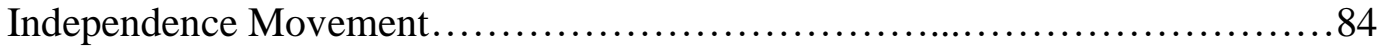

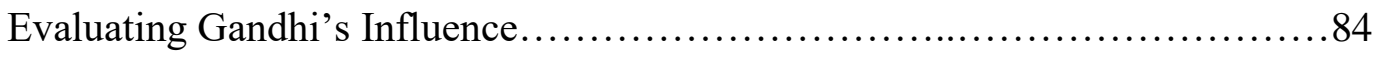

Further Research and Changing

Trends........................................87

REFERENCES.......................................................... 89

CURRICULUM VITA...................................................... 94 


\section{CHAPTER 1}

\section{INTRODUCTION}

\section{Gandhi: The Man}

While many leaders of nationalist movements championed rigorous national, anticolonial resistance in order to engage British colonialism in the $20^{\text {th }}$ century, quite few were able to achieve a level of global influence similar to that which Mohandas Gandhi's satyagraha campaign did. Gandhi's political philosophies which formed the core of his vision of satyagraha were derived from Hindu theologies which demanded truth in justice, a willingness to sacrifice ones' pleasures, and a commitment to non-violent resistance. These three tenets provided the foundation for an anti-colonial framework of resistance that was applicable and relevant to movements across nations, cultures, and religious identities in the Global South.

Mohandas Gandhi, born in Porbandar, India in 1869, experienced British colonial rule from a young age, and consequently, dedicated his life, career, and ambitions towards the emancipation of India, accomplished on August 15, 1947. Gandhi's family were grocers, belonging to the bania caste, and hailed from the state of Kathiawar Gujerat. Within Gujerat, Porbandar was one of the hundreds of states that, in the 19th century, suffered from the political dictations of young, inexperienced prince rulers who made birth claims to royalty. Despite its political backwardness, Porbandar was a famous destination of Hindu pilgrimage, producing religious and social reformers, as well as entrepreneurs. The sacred teachings of Buddha, Mahavira, and Vallabhacharya have a 
profound theological impact on the religious communities, traditions, and cultures of Gujerat, producing a sense of persistence when facing obstacles. This theology indeed reflects the spiritual tenacity of Mohandas Gandhi. ${ }^{1}$

\section{Gandhi: His Life}

Gandhi's mother, Putlibai, had a significant impact on his spirituality, impressing upon him, from a young age, the value of a tenacious, dedicated faith through her routine practices of fasting and practicing vows. Gandhi's views of women, derived from his vision of Putlibai, were characterized by sacrifice and unconditional love, a vision he was able to harness into a transformative approach to issues of community and families within. Gandhi's father, Karamchand, emphasized a personality of truthfulness, loyalty, and generosity, and was a figure whom Gandhi worshipped. A consequence of Gandhi's cultural, spiritual, and familial upbringing, thus, was an undying loyalty to his parents. ${ }^{2}$

Married at the age of 13, Mohandas Gandhi had an isolated and challenging childhood lacking contact outside of the family, as he was attached to familial life and pursuing education from his teenage years on. Gandhi jumped at the opportunity to study at the university level in England, however, his feelings of isolation intensified, as he felt ethnically ostracized in a country, society, and culture that was completely foreign to him. Experiences with vegetarianism and his spiritual refusal to eat meat would further restrict his ability to connect to other students until he found a vegetarian restaurant near

\footnotetext{
${ }^{1}$ B.R. Nanda, Mahatma Gandhi: A Biography. New Delhi: Allied Publishers Private Ltd., 1958, pp. 16

${ }^{2}$ Ibid, pp. 19-20
} 
his university, which created a new sense of identity and self-security in Gandhi. ${ }^{3}$

Vegetarianism was less a matter of scientific beliefs about nutrition, and more so, a theological fervor inculcated deep in Gandhi's psyche, a revelation that fits well into the theology of Satyagraha.

\section{Gandhi: His Philosophy}

Satyagraha was a philosophy which Gandhi formulated into a framework for anticolonial resistance, and he adopted the philosophy for life. Satyagraha is best described as a set of political philosophies designed to maximize the moral leverage of a people who face oppression through their own government or via foreign rule. Popularized as the strategy of non-violent direct action by Mohandas Gandhi during his Non-Cooperation movement in India, satyagraha can be broken down operationally into three tenets: ahimsa, satya, and tapasya. Ahimsa represents a stringent practice of non-violence which features a refusal to injure others, satya represents a truth force derived in Hindu theology in which no religious duty or practice overshadows, and tapasya represents a willingness to sacrifice ones' pleasures in order to obtain dignity. ${ }^{4}$

${ }^{3}$ B.R. Nanda, Mahatma Gandhi: A Biography. New Delhi: Allied Publishers Private Ltd., 1958, pp. 26-30

${ }^{4}$ Bhagavan Sri Sathya Sai Baba, (1988), Discourses on the Bhagavad-Gita. Andhra Pradesh, Sri Sathya Sai Books and Publications Trust, 51-52, J.V. Bondurant, (1965), Conquest of Violence, The Gandhian Philosophy of Conflict. Los Angeles; University of California Press, 112, M.K. Gandhi, (1944), Nonviolence in Peace and War( $\left.2^{\text {nd }} e d.\right)$. Ahmedadad, Navijivan Trust, \& S.E. Jones, (1948), Gandhi, Portrayal of a Friend. Nashville, Abingdon Press, 82 
Satyagraha, Civil Rights Movements, and Social Activism

Gandhi's political philosophies of non-violence had a tremendous impact on Martin Luther King Jr. and the African American Civil Rights Movement, on Nelson Mandela and South Africa's Independence Movement, as well as on contemporary peace activists, Mubarak Awak and Aung San Suu Kyi, who practice non-violence respectively in Palestine and Myanmar.

In “A Retrospective on the Civil Rights Movement: Political and Intellectual Landmarks," Aldon D. Morris records the influence of Gandhi's political philosophies of non-violence on the African American Civil Rights Movement. ${ }^{5}$ Morris finds that Gandhi's employment of nonviolence was significant to leaders among civil rights movement like James Farmer, Bayard Rustin, James Lawson and Glenn Smiley, all who had studied Gandhi's movement through its influence over the Black Church and intellectual leaders of its clergy. Farmer, Rustin, Lawson, and Smiley, came to view Satyagraha as a tool that could be used in the interests of the African American Freedom Movement. Additionally, Morris's work records that Gandhi heavily influenced Martin Luther King Jr. and that through this interaction, the African American civil rights movement led by King Jr. modernized the practice of nonviolent direct action.

Sally Avery Bermanzohn observes and analyzes non-violence as an effective antiracist strategy in the Civil Rights Movement to combat state-sanctioned and extrajudicial, racist violence against blacks in the South. ${ }^{6}$ She also details the relationship between

\footnotetext{
${ }^{5}$ Aldon D. Morris, "A Retrospective on the Civil Rights Movement: Political and Intellectual Landmarks" Annual Review of Sociology, 25 (1999): 517-39, http://www.jstor.org/stable/223515

${ }^{6}$ Sally Avery Bermanzohn, 2000, "Violence, Nonviolence, and the Civil Rights Movement.” New Political Science, 22 (1): 31-48, doi:10.1080/073931400113503
} 
Gandhi and Martin Luther King Jr. and specifically, Martin Luther King Jr.'s incorporation of Gandhi's satyagraha principles in regards to his non-violent campaign, which was largely installed among black churches in order to spread the message. She writes: "King felt that Gandhi's philosophy was 'the only morally and practically sound method open to oppressed people in their struggle for freedom.' He [King] described Gandhi's nonviolent resistance as "one of the most potent weapons available". 7 Bermanzohn concludes by arguing that non-violent political resistance, combined with armed figures of self-defense, defeated climates of anti-black racist violence caused by white supremacist groups in the Southern U.S. in the 1950s and 1960s. Her work contextualizes the material situation in which satyagraha served as anti-racist and anticolonialist political strategy.

Similarly, Simon Wendt discusses how non-violence and satyagraha were employed in a localized struggle in Tuscaloosa Alabama, within the broader African American Freedom Movements that swept the U.S. political and social landscapes of the 20th century. Wendt views the non-violent influences of Gandhi as a primary influence on a larger campaign among black churches of political agitation and resistance to racism. ${ }^{8}$ Discussing the campaign led by Baptist minister T.Y. Rogers, Wendt writes (2004): “Impressed by Rogers' charisma and his unwavering determination, more and more people attended the Monday night rallies. Throughout April and May, at least four

${ }^{7}$ Ibid, pp. 42

${ }^{8}$ S. Wendt, (2004), God, Gandhi, and Guns: The African American Freedom Struggle in Tuscaloosa, Alabama, 1964-1965, The Journal of African American History, 89(1), 3656, Retrieved from http://www.jstor.org/stable/4134045 
hundred people regularly crammed into First African Baptist Church, responding with cheers to Rogers' eloquent oratory. He preached Martin Luther King's philosophy of Christian love and Gandhian nonviolence". ${ }^{9}$ Wendt's work draws on archived primary sources and in doing so, reveals Gandhi's influence on churches and church movements as a part of the Civil Rights Movement.

While social histories of colonialism have widely recognized the influence of Gandhi and satyagraha on internationally prominent civil rights leaders, such as Nelson Mandela and Martin Luther King Jr., the influence of Gandhi and satyagraha on contemporary peace activists like Mubarak Awad and Aung San Suu Kyi has not been widely documented in scholarship. This gap in literature is worth recognizing because Gandhi's philosophy of satyagraha has a profound influence over contemporary peace movements and many of the activists which lead them. Mubarak Awad argues that nonviolent political protest, combined with armed defense, has been an integral force in the Palestinian movement against Zionism since the 1930s. ${ }^{10}$ Aspects of ahimsa are recognized in the Awad's mission to humanize the Israeli soldier whose career and duty expects him to kill Palestinian martyrs. Awad's work also documents the political positions of nonviolence and methods used to accomplish goals within the Palestinian freedom movement. On the methodology of civil disobedience, Awad writes:

"One aspect of non-violence that is worth emphasizing in this respect is that the Palestinians would be voluntarily accepting and rejoicing in the persecution and suffering inflicted on them. Bravely and steadfastly to accept persecution for one's

\footnotetext{
${ }^{9}$ S. Wendt, (2004), God, Gandhi, and Guns: The African American Freedom Struggle in Tuscaloosa, Alabama, 1964-1965, The Journal of African American History, 89(1), pp. 43

${ }^{10}$ Mubarak E. Awad, "Non-Violent Resistance: A Strategy for the Occupied Territories." Journal of Palestine Studies 13, no. 4 (1984): 22-36. doi:10.2307/2536988
} 
believes brings one very close to the power of non-violence. It neutralizes the effectiveness of the instruments of repression and improves the internal steadfastness and power of the resister". ${ }^{11}$

The implications of Awad's theological understanding of satyagraha, as a scholar who emphasizes a non-violent approach to Palestinian freedom movements, are significant in illuminating Gandhi's continued influence through the teachings of his political philosophies.

Aung San Suu Kyi is a contemporary peace activist from Myanmar whose work, like that of Mubarak Awad, is deeply influenced by Gandhi's teachings of non-violence as political resistance to colonial occupation. Suu Kyi has stated that Mohandas Gandhi and his writings on non-violence were the principles which inspired her political activism, career, and approach. ${ }^{12}$ Their vision for satyagraha is united in their shared emphasis of upholding human rights, democracy, reconciliation between groups, non-violence, and practical, personal and collective discipline. Suu Kyi exhibits the fearlessness in political resistance that Gandhi advocated among satyagrahis, as in 1988, despite government threats of interference, she persistently vocalized the demands of common people to her government. ${ }^{13}$ Thus, while Gandhi and satyagraha had a profound impact on prominent civil rights leaders during the 1920s to 1960 s, Gandhi's influence has a presence among

\footnotetext{
${ }^{11}$ Mubarak E. Awad, "Non-Violent Resistance: A Strategy for the Occupied Territories." Journal of Palestine Studies 13, no. 4 (1984): pp. 35

${ }^{12}$ Aung San Suu Kyi, Burma and India: Some Aspects of Intellectual Life Under Colonialism, Allied Publisher, New Delhi, pp. 58

${ }^{13}$ Award ceremony speech, http://www.nobelprize.org/nobel_prizes/peace/laureates/1991/presentationspeech.html
} 
peace activists today, and in that, the tangibility of his vision for satyagraha across different social and political contexts is recognized.

\section{Gandhi's Influence in South Africa}

Mohandas Gandhi would earn a degree that gave him the status of a barrister in legal study, however, he was not able to make a sufficient living for himself and his family without additional training in Bombay, and was led through roadblock after roadblock. As it would turn out, Gandhi would have another international journey waiting for him in the opportunity of a new job offer in a position of legal counsel in South Africa. South Africa would serve as a bedrock for Gandhi's civil rights career, wherein he established the Natal Indian Congress, to argue for the interests and protections of communities of Indians in South Africa. From the end of the 19th to the beginning of the 20th century, Gandhi would find himself locating, and relocating, between South Africa and India, assessing issues of colonial rule of Indians in both countries. However, upon returning to India from South Africa, a significant shift occurred not only in Gandhi's career but in his core belief system. He began a transformational religious journey towards traditional Hindu theologies of aparigraha (non-possession) and sambhava (equitability). ${ }^{14}$ It is in conjunction with these two theologies in which Gandhi's philosophy of satyagraha was derived.

Gandhi's influence was significant in South Africa's decolonization and independence movements. Nelson Mandela and South Africa were influenced both by

${ }^{14}$ B.R. Nanda, Mahatma Gandhi: A Biography. New Delhi: Allied Publishers Private Ltd., 1958, pp. 40-70 
Gandhi's techniques of civil disobedience, as well as by his strategies of political resistance to colonial occupation. In "The Sacred Warrior", a brief biography of Gandhi's work and influence, Mandela outlines what Gandhi's thinking and influence offered the colonial theatre of South Africa, as well as his personal adoptions and critiques of Gandhi's satyagraha, illuminating some of the manners in which he may have been influenced through Gandhi. ${ }^{15}$ Mandela writes:

"The Gandhian influence dominated freedom struggles on the African continent right up to the 1960s because of the power it generated and the unity it forged among the apparently powerless. Nonviolence was the official stance of all major African coalitions, and the South African A.N.C. remained implacably opposed to violence for most of its existence... there came a point in our struggle when the brute force of the oppressor could no longer be countered through passive resistance alone... Gandhi himself never ruled out violence absolutely and unreservedly "Where choice is set between cowardice and violence, I would advise violence... I prefer to use arms in defense of honor rather than remain the vile witness of dishonor...". 16

The Times article details Mandela's vision of satyagraha and its implications in resisting apartheid in South Africa, which serve to reveal Gandhi's influence in South Africa's independence movements, particularly among South African Indians.

Indians who began traveling to South Africa as early as the 17th century served as inter-continental merchants, local businesspeople, and other professional/service roles. Thus, by the time South African apartheid was established politically, a significant Indian population had already amassed in South Africa. Apartheid politics meant that Indians would be placed within the racial hierarchy already existing in the country, and would be

\footnotetext{
${ }^{15}$ Nelson Mandela, "The Sacred Warrior." Time, December 31, 1999, 1-3, http://content.time.com/time/subscriber/article/0,33009,993025-3,00.html

${ }^{16}$ Ibid, p. 1
} 
socially designated as 'non-Europeans', meaning that Indians and Africans could be treated with little distinction politically.

Uma Dhupelia-Mesthrie's (2004) Gandhi's Prisoner provides a thorough biography of the life, travels, and work of Manilal Gandhi, son of Mohandas Gandhi, as an Indian businessman/merchant whom would frequently travel between India and South Africa. The literature reflects the anti-colonial perspectives of Manilal's father, who shaped and guided his understandings of and work in South Africa, would come to understand apartheid South Africa as racist, oppressive, and in need of legal and political correction:

"[Mohandas] Gandhi found that the British efficiently implemented the existing discriminatory laws and sought to impose new ones. The Transvaal had some of the most restrictive laws against Indians... The newly established Asiatic Department, with the power to determine which Indians could enter the Transvaal, became the focus of Gandhi's attention". ${ }^{17}$

Gandhi's life did not only direct influence anti-colonial freedom movements, but he also encouraged others, like his son, to advocate against colonialism. A vivid example of his influence can be observed in a South African newspaper he started in 1903, called Indian Opinion, which tracked global news during the colonial era with an emphasis in subcontinental India and continental Africa coverage. Manilal Gandhi would closely associate with Indian Opinion during the mid $20^{\text {th }}$ century in championing the cause of bringing equity to relations between Whites and Indians in South Africa, and in that association, espoused his father's philosophical and political influences in South Africa through the Indian Opinion.

${ }^{17}$ Uma Dhupelia-Mesthrie, Gandhi's Prisoner?: The Life of Gandhi's Son Manilal, Cape Town: Kwela Books, (2004), p. 50 
Gandhi's influence in South Africa, as an anti-colonial actor whom professed a rigid discourse which fought for equal rights for South African Indians during apartheid, did not go without ethical controversies related to its social context. In The South African Gandhi, Ashwin Desai and Goolam Vahed argue, “Gandhi's views on race, class, caste, nation and Empire are contentious and even distressing at times to his supporters". ${ }^{18}$ While in South Africa Gandhi's political focus fixated on bettering the lives of Indians rather than all groups in South Africa. As a result, Gandhi often deployed racialized rhetoric to distance Indians from Africans in the eyes of the British Empire. Gandhi's use of the derogative term Kaffir when locating the social identity of the African is viewed contemporarily as an exclusion of Black South Africans. Gandhi's failure to acknowledge anti-black racial discriminations as the principal mechanisms of segregation within colonial South Africa. In arguing that Europeans and Indians shared a similar bloodline, Gandhi also appeared dependent on a "racial imaginary" that ultimately recognize Africans as equals to other British subjects (i.e. Indians) and thus consciously avoided building coalitions with Africans in the pursuit of his political agenda. ${ }^{19}$

However, Gandhi's influence in South Africa as an anti-colonial actor was not fully disconnected from the plight of Black South Africans. His satyagraha ideology, political activism, and their influence ultimately shaped prominent African political leaders (i.e. Nelson Mandela, Oliver Tambo) and African political parties (i.e. the African National Congress). While Gandhi's intentions in South Africa may not have been to produce a multi-racial solidarity in resisting colonial rule or racial segregation,

\footnotetext{
${ }^{18}$ Ashwin Desai and Goolam Vahed, The South African Gandhi: Stretcher-Bearer of Empire, Stanford: Stanford University Press, 2015, pp. 26

${ }^{19}$ Ibid, pp. 61
} 
satyagraha played an important role in that productive process, and shaped grassroots activism long after Gandhi relocated to India. Thus this project focuses on framing the influence of satyagraha in the coverage of the Indian Opinion and therefore teases out its impact among South African Indian communities throughout the 1950s.

\section{South Africa and India}

In South Africa and India, Isabel Hofmeyr sets out to provide a historical examination of social, political and economic relations between South Africa and India, as well as, to draw meaningful socio-political comparisons, highlighting the striking similarities as well as differences, between their political and social phenomena. Hofmeyr's primary argument asserts that, in drawing these comparisons, research helps to dispel notions of distinct or isolated continental experiences of colonialism by encouraging societies to not only look at regional but global connections, particularly in resistance to colonial force. ${ }^{20}$

In a chapter entitled "Democratic Deepening in India and South Africa," Hofmeyr records that civil subordination of citizens, in South Africa via apartheid and in India via the caste system, prevented a liberation of participatory and electoral processes that otherwise would have been a result of the historic consolidation of democracy that took place among the countries. Hofmeyr argues that this subordination is particularly consequential in three ways: "A weakened society cannot perform three critical democratic functions: (1) providing a space in which citizens can meaningfully practice

\footnotetext{
${ }^{20}$ Isabel Hofmeyr, and Michelle, Williams, South Africa and India: Shaping the Global
} South, Johannesburg: Witwatersrand University Press, 2011 
democracy on a day-to-day basis; (2) anchoring the legitimacy of political practices and institutions in vigorous public debate; and (3) serving as a countervailing force to the power-driver logic of political society". ${ }^{21}$ Given that a historical symptom of democratic transitioning is the weakening of civil society, the tension between civil and political society illuminates potential immense consequences of attempting to produce a 'deepened democracy' in a weakened civil society which subordinates various groups of citizens. Thus, Hofmeyr's argument emphasizes how in South Africa, racial apartheid restricted any liberalizing application of democracy, which ultimately, reveals the prevalence of social control in Global South politics during the $20^{\text {th }}$ century.

Hofmeyr's conclusive remarks display her view that linkage and circulation existed within the Global South, as a political imaginary which shapes intergovernmental activity, trade agendas, and the work of non-governmental organizations in the South Asian/African regions. The comparative analysis ultimately yields fruitful insight into the South African/ Indian relationship: both illustrating how they assert imperialisms in their unique colonial experiences, and when they engage in cooperation to resist colonial force. Hofmeyr establishes this view in the final pages of her work, displayed by the pursuit of her work and arguments "to signal the dilemmas of ethical judgment and action concerning India and South Africa in ways that are perpetually in motion, as both countries carry along a closely linked past while fashioning a more closely intertwined future". ${ }^{22}$ Hofmeyr's literature carries great relevance to scholarly discussions of labor relations, social theory, and the advancement of democracy within Indian and South

${ }^{21}$ Isabel Hofmeyr, and Michelle, Williams, South Africa and India: Shaping the Global South, Johannesburg: Witwatersrand University Press, 2011 pp. 151

${ }^{22}$ Ibid, pp. 267-268 
African societies. Hofmeyr's comparative analysis is thorough among the subjects she attends to, and she makes descriptive connections between the societies in her findings. Due to the uniqueness of her methodology in observing relations between two countries, the conclusions she derives from her subject "lenses" are noteworthy and helpful in laying out a new framework of cooperative research among Global South economies and societies. Furthermore, her work, as a compilation of works and essays surrounding colonial and anti-colonial relationships in South Africa and India, is deeply relevant to the examinations of this paper as it aids in the identification and evaluation of labor economies and social/political traditions which linked anti-colonialist Indians in South Africa and India with continental Africans.

Additionally, Hofmeyr's work discusses the influence that the introduction of Gandhi's printing press, steamboats, trade unionism among African and Indian sailors had on labor economies. Hofmeyr focuses on the relationship of the press which the Indian Printing Press, and in association with Gandhi, the Indian Opinion produced in order to discuss the cultural commodification of the greater maritime economy, proposing: "The IPP was avowedly cosmopolitan in its personnel, methods of working, textual products and their envisaged audiences. It supported a form of textual circulation and modes of reading that straddled the Indian Ocean and helped bring into being the universalisms and cosmopolitanisms uniting different groups across the sea". ${ }^{23}$ In addition, she finds that, within this greater process of maritime economy, a similarity can be drawn, for South African historians, to the labor history of gold mines: a history where

${ }^{23}$ Isabel Hofmeyr, and Michelle, Williams, South Africa and India: Shaping the Global South, Johannesburg: Witwatersrand University Press, 2011, pp. 36 
access to cheap unskilled labor was provided to colonial governments, and yet, upon demands by white labor groups who feared loss of employment, was eventually resisted.

\section{Indian Opinion}

Indian Opinion, a South African newspaper founded in 1903 by Mohandas Gandhi, Madanjit Viyavaharik, and Mansukhlal Nazar, served as a publication in the movement of racial progress for immigrant Indians in South Africa. While one of the Indian Opinion's primary functions was to bring equity to political relations between Whites and Indians in South Africa, Gandhi's work with the Indian Opinion also explored legal and legislative issues for Black South Africans, such as Gandhi's resisting of the Native Land act of 1913, which "set aside just 7\% of South Africa's land for black ownership". ${ }^{24}$ It is worth recognizing that Gandhi, in South Africa, did not view Indians and Black South Africans as social equals, rather, he preferred a view which equalized Indians and White South Africans. Still, Mohandas Gandhi's exploration of the political concerns of Black South Africans served as a diving board for which Manilal Gandhi could articulate multi-racial solidarity among all people of color in South Africa as resistance to $20^{\text {th }}$-century colonialism and apartheid.

Les and Donna Switzer's (1979) The Black press in South Africa and Lesotho: A descriptive bibliographic guide to African, Coloured, and Indian newspapers, newsletters, and ... and guides in African studies, dedicates a full biographical entry to

${ }^{24}$ Uma Dhupelia-Mesthrie, Gandhi's Prisoner?: The Life of Gandhi's Son Manilal, Cape Town: Kwela Books, 2005, pp. 111 
the founding, rise, and eventual fall of Indian Opinion as a major Indian newspaper

reaching South-African, Indian audiences:

"The first Indian newspaper in South Africa was founded by V. Madanjith (cited by the 1950 Press Commission) and Mohandas Karamchand Gandhi (cited by Pachai), the pioneer tactician of passive resistance, in Natal. It was printed by the first Indian-owned press (International Printing Press) in Durban and, from 1904, at Phoenix Settlement, the communal farm Gandhi established outside the city... Gandhi's legacy 'of moderation and compromise' was continued by his successors, but the influence of Indian Opinion waned in the harsher realities of South Africa after World War I". ${ }^{25}$

During the years in which Indian Opinion ran at peak activity in global press cycles, it accomplished a great deal in serving to deliver a 'Gandhian' interpretation of mostly headline Indian and South African news, and is thoroughly useful for examination as a primary source which will illuminate the role of satyagraha and non-violent direct action in South Africa's de-colonization movement. From the 1950s-1960s, Indian Opinion's coverage revealed South African interpretations of colonialism and anti-colonial activism in Ghana and Kenya. In these revelations, Indian Opinion was highlighting and describing major events of colonialism and independence movements while contextualizing them with an anti-colonial discourse which was derived from Gandhi's principles of satyagraha.

\section{Methods}

In summary, this literature review discusses the influence of Gandhi's political philosophies of non-violence on Nelson Mandela and the South African Independence

${ }^{25}$ Switzer, Donna \& Switzer, Les. The Black press in South Africa and Lesotho: A descriptive bibliographic guide to African, Coloured, and Indian newspapers, newsletters, and ... and guides in African studies. Boston: G.K. Hall \& Co., (1979), pp. 41-42 
Movement, Martin Luther King Jr., and the African American Civil Rights Movement, and contemporary peace activists such as Mubarak Awad of Palestine and Aung San Suu Kyi of Myanmar. The selected literature depicts the influence of Gandhi and satyagraha in international Civil Rights Movements in the practice of civil disobedience, satya and ahimsa as truth and self-sacrifice, and non-violent direct action as political resistance. These factors or elements of satyagraha, among others, are useful in the examination of Gandhi's influence across Global South decolonization movements.

This research project captures South African Indian interpretations of Ghanaian and Kenyan independence movements, from 1950-1960, using the Indian Opinion. Although Indian Opinion was not the only South African newspaper whom reported to a predominantly Indian audience, it was a key institution of journalism seeking to fulfill this role during the early to mid 20th century. In its reporting on British colonialism and anti-colonial activism in Kenya and Ghana, the newspaper also presents itself as a relevant source in framing the influence of Gandhi's political philosophy of satyagraha on the Mau-Mau Uprising \& the Ghanaian Independence Movement.

First, each independence movement is contextualized by secondary sources that describe the historical characteristics and socio-political conditions of colonialism in East and West Africa prior to the onset of an established anti-colonial movement. Next, data from archived research on the Indian Opinion's coverage and interpretations of each independence movement occurring in Kenya and Ghana are analyzed in order to better understand how South African Indians were viewing anti-colonialism in Africa, as well as to explore Gandhi's potential influence on the independence movements. Finally, the colonial response to each independence movement is examined through postindependence coverage in the Indian Opinion of de-colonization movements in Kenya 
and Ghana. The concluding discussions of the project seek to identify and address any similarities and differences in how Indian Opinion was interpreting anti-colonialism and independence movements in Kenya and Ghana, as well as, to elaborate upon future research and discuss changing trends.

This research project aims to answer two primary questions: In what ways did Gandhi's political philosophies of non-violence influence/inform leaders, activists, and movements across the Global South during the 20th century, and did diasporic interactions between Africans and Indians in the Global South yield or reflect a shared anti-colonial identity in resistance to British colonial rule? In answering these questions, this study seeks to identify in what ways satyagraha impacted the anti-colonial activisms of Indians and Africans in colonial Kenya and Ghana, and describe how this impact engendered negotiations on South Africa Indian views and interpretations of violent and non-violent resistance to colonialism. This research is exploratory in approach, aiming to add to current scholarly conversations on ethnicity, diasporic relations and non-violent political resistance in the Global South.

The sample of Global South independence movements and their associated leaders/activists chosen in this study are intended to reflect the diverse positions in which the influence and development of satyagraha's truth, sacrifice, and non-violence justice principles can be observed as relevant to interpretations of colonial resistance. Assessing the assumed influence of Gandhi's political philosophies of non-violence on leaders of anti-colonial movements in the Global South will be performed through the investigation of the Indian Opinion as a primary source. Historical analysis of secondary sources, i.e. prior research, will serve to contextualize and provide a background to Indian Opinion's coverage of the Mau Mau uprising and the Ghanaian Independence Movement. 
Utilization of this triangulation and interdisciplinary research allows a fullspectrum illustration of Gandhi's influence, not only on leaders or individuals within movements, but on diasporic transactions between Africans and Indians in the Global South during the 20th century. This project specifically is informed by Pan African schools of thought that emphasizes the significance of centering modern history in the experiences of Africans. Molefi Asante discusses this significance in his writings on Afro-centricity: "Afrocentricity is the belief in the centrality of Africans in postmodern history. It is our history our mythology our creative motif and our ethos exemplifying our collective will". ${ }^{26}$ Under an Afro-centric framework, this project centers the colonial experiences of West and East African in Ghana and Kenya in South African Indian interpretations of Global South Independence movements. In this perspective, the project views Indian Opinion's reporting of anti-colonial activism in Ghana and Kenya as emerging African nationalisms who resisted British colonialism in the $20^{\text {th }}$ century. Further, the project records the influence of Gandhi's political philosophies in interpretations of each movement in order to situate the role of violence and non-violence as manifestations of colonial resistance.

Ultimately, this research seeks to understand British colonialism in the 20th century as a global enforcement of Anglican values and culture, and interprets political resistance to that colonialism as a deliberate inter-ethnic rejection of the enforcement of Anglican values and culture. This study locates the Mau Mau uprising and the Ghanaian Independence Movement as emerging African nationalisms in the 1950s to 1960s, examining the similarities and differences of Indian Opinion's interpretations of British

\footnotetext{
${ }^{26}$ Molefi K. Asante (2003), Afrocentricity, African American Images
} 
colonialism and anti-colonial activism in Kenya and Ghana. In the performance of this comparative analysis, the study seeks to reveal the Indian Opinion's anti-colonial agenda and its influences on its majority South African Indian readership, shedding light on their varying perceptions of violent and non-violent anti-colonial activisms as rejections to mid-20 ${ }^{\text {th }}$ century British colonialism. Through a comparison of South African Indian views on non-violent and violent anti-colonial activisms in Kenya and Ghana, the research also displays the global influence of Gandhi's political philosophy of satyagraha and its three foundational tenets: 1) ahimsa, the non-violent refusal to injure others, 2) satya, a theological conceptualization of Truth, and 3) tapasya, the willingness to sacrifice one's pleasures in order to obtain dignity. 


\section{CHAPTER 2}

\section{INTERPRETATIONS OF ANTI-COLONIAL ACTIVISM IN}

KENYA, 1950-1960

\section{Background to the Mau Mau Uprising}

The colonial history of Kenya sprang about in 1885, when the Berlin conference launched the "Scramble for Africa" and European powers like Britain, Germany, Italy, France, Spain, Portugal, and Belgium set out to acquire colonies throughout the African continent. Britain, at the conclusion of the 1885 conference, acquired British East Africa, and thus, became the colonial ruler of Kenya. ${ }^{27}$ This period of continental African history termed the "Scramble for Africa", represents a late 19th-century insurgency of European colonialism upon Sub-Saharan nations.

European colonial domination of Africa began with the widespread practice of free trade imperialism, seeking to extract natural resources and raw materials through the building of commercial relations. The process of free trade imperialism produced several economic consequences on African workers: coerced labor, low wages, and racial discrimination where applicable. Colonial institutions enforced social segregation in order to establish boundaries between settlers and colonial subjects. Political ambitions

${ }^{27}$ Matt Rosenburg, "The Berlin Conference of 1884-1885 to Divide Africa." ThoughtCo, 24 Sept. 2018, www.thoughtco.com/berlin-conference-1884-1885-divide-africa-1433556 
of local governments offered economic protections to settlers and their interests. It was under these economic, social, and political conditions in which African nationalisms emerged during the 1920 s across Africa. ${ }^{28}$

African nationalisms sought to challenge the colonial view of pre-colonial African governments and societies, illustrating the political imperative of achieving liberation from colonial rule and of the forming of post-colonial nations. In practice, nationalisms achieved this purpose through the territorial re-framing of movements and interests which appeared distinct from one another. Even though African nationalisms contained varying political and ideological positions, including positions which engendered distinct views on the application of violent and non-violent anti-colonial activisms, they were united by their anti-colonial vision and their yearnings for an independent Africa. ${ }^{29}$ By the conclusion of World War II, mass nationalisms were beginning to bloom in East Africa, as a result of increased production in export crops, as well as any associated increases in needs for low-wage labor forces. The Kikuyu, Meru, and Embu peoples were cornered both geographically, through the continued, domineering European settlement of indigenous lands, and politically, as the gestation of local governments maintained and advanced the colonial regime and the agenda of settlers who interests the regime protected. Through the re-framing of indigenous movements and their associated interests as interconnected in a wider, national struggle against British East African colonialism, Jomo Kenyatta and other anti-colonial activists in Kenya would garner the political

\footnotetext{
${ }^{28}$ Toyin Falola, Africa, Vol. 4, Carolina Academic Press, 2002, pp. 5-6

${ }^{29}$ Ibid, pp. 8-10
} 
support needed to stage the Mau Mau uprising in the early 1950s as an armed movement of anti-colonial resistance. ${ }^{30}$

\section{$\underline{\text { Indians in Kenya }}$}

While Kenyan Indians did not face the same conditions under British colonialism as did the Kikuyu, Meru and Embu people, they were never accepted into a European settler class either. The short and long history of Indians in Kenya, examined briefly, emphasizes how Indians were viewed and treated as a set of migratory laborers, and illuminates some of the differences and commonalities this treatment entailed with the colonial experiences of East Africans in Kenya.

Indian presence in East Africa was first recorded by an unknown, Koine Greek writer. In 60 A.D., the writer produced a work titled "Periplus of the Erythraean Sea", which explored navigation and trading along the coasts of the Red Sea, the Horn of Africa, and Southwest India. ${ }^{31}$ The work documented centuries of trade networks between Indian and Swahili merchants which came into formation before European exploration and colonialism of East Africa. During the early $20^{\text {th }}$ century, an influx of over 30,000 Indians migrated to East Africa in search of economic opportunities which included the construction of Kenya's "Lunatic Line", a railway connecting Uganda to Kenya. ${ }^{32}$ Indians in Kenya were not only informed by India's colonial experience with Britain but also, by British colonialism in East Africa, forming a shared legacy with

\footnotetext{
${ }^{30}$ Toyin Falola, Africa, Vol. 4, Carolina Academic Press, 2002, pp. 23-24

${ }^{31}$ Eivind Seland, (2016), "The Periplus of the Erythraean Sea: A Network Approach," Asian Review of World Histories, 4(2), pp. 191-205

${ }^{32}$ Nile Green, (2012), “Africa in Indian Ink: Urdu Articulations of Indian Settlement in East Africa," The Journal of African History, 53, pp. 131-150
} 
Kenyan Africans. This legacy, at times, would produce political solidarity and would function to resist racial discrimination and economic exploitation as mechanisms of British colonialism which affected both groups. However, at other times, the legacy would appear tarnished, and Indian Opinion's South African Indian readers would observe some of the more passive tendencies of the anti-colonial resistance of Kenya's Indians.

The South African Indian Interpretation

South African Indians, who make up a large chunk of the readership of the Indian Opinion, share commonalities, and express differences, with Kenyan Indians, as reflected by their experiences with British colonialism. The subcontinental experience of British colonialism in India substantially affected the anti-colonial perspectives of various members throughout its diaspora, including Indians in South, West, and East Africa. This experience, through the economic and political oppression of Hindu and Muslim Indians by British colonialists, showed Indians throughout the diaspora how European colonialism intended to divide its subjects and exert political control over them.

The anti-colonial activism of Mohandas Gandhi was also influential throughout the Indian diaspora, emphasizing the role of non-violence in manifestations of political resistance to colonial rule. Both Kenyan Indians and South African Indians participated in early $20^{\text {th }}$ century indentured servitude in colonized nations of Africa, facing some of the same insufferable employment conditions that Africans were subjected to in forced labor and labor recruitment campaigns. The primary difference among the early $20^{\text {th }}$ century colonial experiences of South African Indians and Kenyan Indians is the event of South African apartheid, and its consequences on the socio-political formation of Africa, 
as a continent, during the era of independence. Thus, it is necessary to explore the nuanced colonial functions of racial construction and division, the establishment of local governance, and settler domination of indigenous lands in colonial Kenya. The following literature review examines euro-centric ideologies of race, local government, and land settlement, as precursors to the formation of the Mau Mau uprising, in order to reveal the nuanced socio-political conditions of British colonialism which shaped the early $20^{\text {th }}$ century colonial experience of Kenyan Indians and Africans.

\section{$\underline{\text { Race, Local Government, and Land Settlement }}$}

In Race and Empire: Eugenics in Colonial Kenya, Scholar Chloe Campbell performs an in-depth study of the eugenics movement in Kenya during the inter-war years. In exploring the operation of racial constructs within British colonial society, Campbell's describes the influence of eugenic movements in imperial projects and illuminates the "transportation and mutation of British eugenic thought as it moved through the imperial conceptual network" ${ }^{33}$ Campbell identifies three traditions of British Eugenics- heredity, meliorism, and Malthusianism, detecting the presence of heredity and meliorism eugenics in Kenya's Eugenics movement. Campbell evidences the emphasis of biological debates on innate racial difference through its impact on Colonial policies to 'promote African development. The strength of the work is in Campbell's ability to demonstrate how different eugenicist movements were influenced by national cultures and replicated various political and social ambitions. In Kenya, Campbell emphasizes the manner in which race discourses produced European anxieties

\footnotetext{
${ }^{33}$ Chloe Campbell, Race and Empire: Eugenics in Colonial Kenya, Manchester University Press, 2007, pp. 3
} 
of Africans, illuminating the basis for which Europeans in South Africa and Kenya attempted to establish "white-only" rule. Also, Campbell's discussion of race illustrates how Europeans viewed colonialism as a civilizing mission to the African continent, particularly in East Africa. Finally, Campbell usefully identifies networks which depict race discourse and connects Kenya to other settler states, notably, South Africa.

Scholar Patricia Stamp's work, "Local Government in Kenya: Ideology and Political Practice, 1895-1974", illustrates political practices and ideologies who engendered the actions of local government in Kenya during the late $19^{\text {th }}$ and early to the late $20^{\text {th }}$ century. Stamp emphasizes the manner in which British colonialists dismissed the existence, let alone viability, of pre-colonial governments in Kenya, and argues that local governments protected the interests of a social, political and economic bourgeoise from the class-based interests of central governments. Stamp discusses the Local Government Reform Act of 1888, which dictated the terms of the political and economic relationship between local and central governments, and established a need for the development of local governments, rather than central governments, in Kenya. Stamp notes that the development of the British local government system occurred in two phases. The first phase, occurring between the 1880s and 1950s, sought to establish colonial control in less-settled areas of Kenya. The second phase, occurring after the 1950s, aimed to clarify the functions of the local government, including an imperative engaging with concerns of representation. ${ }^{34}$ Stamp argues that local government practices in Kenya during the late $19^{\text {th }}$ to late $20^{\text {th }}$ century focused on establishing the interests of a

\footnotetext{
${ }^{34}$ Patricia Stamp, (1986), "Local government in kenya: Ideology and political practice, 1895-1974." African Studies Review, 29(4), 1-17. doi:10.2307/524004
} 
small bourgeoisie class through the advancing of ideologies which connected local government protectionisms to the development of Kenya.

The primary interests which local governments fixated on advocating were the interests of British settlers in Kenya, who needed political and economic protections in order to compete with pre-colonial, agricultural economies of the Kikuyu. In Colonial Challenges and Administrative Response: Sir Charles Eliot and 'Native' Trusteeship in Kenya, 1901-1904, scholar L.I. Izuakor describes how the settlement of Europeans in Kenya challenged the establishment of trusteeships, and in that challenge, necessitated that protections of settler interests be viewed as uplifting to the 'native'. Izuakor uses the prominent British agent of colonialism in early $20^{\text {th }}$ century Kenya, Sir Charles Eliot, to describe how trusteeships were conceptualized, and the purposes they served in the view of the colonial regime. Referencing the contact strategy, Izuakor records the political and economic relationships European settlers wished to establish with the Kikuyu, including the "assurance of an abundant supply of cheap African labour for the European farms" and "bringing the benefits of European civilization to the door steps of Africans". ${ }^{35}$ While this relationship appears symbiotic, the ideologies and theories which predicate European colonialism as civilizing in Africa are dogmatic and prejudiced against the African. Reflecting on what some colonial officials considered to be the cause of the Mau Mau uprising, Izuakor displays how colonial settlements of land and increased Westernization

${ }^{35}$ Levi Izuakor, (1988), "Colonial Challenges and Administrative Response: Sir Charles Eloit and 'Native' Trusteeship in Kenya, 1901 - 1904." Transafrican Journal of History, 17, p. 38 
were advanced out of colonial conceptualizations of trusteeships, which manifested economic and political impositions on the African in Kenya.

Constructions of race, the transition from central governments to local governments, and land settlement by Europeans provide a background to the colonial experience in Kenya under British colonial rule. Through the analysis of East African colonialism and anti-colonialism via the Indian Opinion, this chapter examines and explores how South Africans Indians were viewing British colonialism in East Africa, specifically, how the Indian Opinion was interpreting the Mau Mau uprising as a response to the colonial state in Kenya. In performing such an analysis, scholarly historical commentary on colonialism in East Africa is juxtaposed with the particular emphases of the reporting of colonialism by Indian Opinion, in order to reveal differences and similarities in how South African Indians were interpreting, and how Kenyan Indians were experiencing, colonialism in East Africa.

\section{Perspectives on the Social Context of the Mau Mau Uprising}

From 1950-1952, the Indian Opinion's coverage was predominantly concerned with documenting the social circumstances and political mechanisms of colonial rule leading up to the Mau Mau uprising, who began in October 1952. This acute period of Kenyan history, as interpreted by this South African Indian newspaper with a predominantly South African Indian readership, exhibited a cycle of legislature which advanced the political interests of colonial settlers in the forms of land acts, the formation of councils whom produce unequal representation for indigenous East Africans, and the division of colonial subjects through religious and ethnic identity. This period of Indian 
Opinion's coverage navigates the circumstances which urged its predominantly South African Indian audience to re-negotiate 'Gandhian principles' of non-violence in favor of a more direct resistance to British colonialism in East Africa. This analysis seeks to better understand how South African Indians navigate their socio-political views of nonviolence while observing and interpreting violent colonial rule, as well as the rise of anticolonialism in Kenya.

The fact that Indian Opinion dedicated a section, the "Kenya Letter", during the 1950-1960s, to happenings in Kenya, reflects its concern with the presence of Indian communities in colonial East Africa. The very presence of the column, in contrast to the relative lack of coverage on Ghana, emphasizes the presence of a diasporic relationship between Indians in Kenya and South Africa. This diasporic relationship makes common an experience of European colonial oppression on the African continent. At the beginning of the decade, the "Kenya Letter" column brought news of Kenya and East Africa to the attention of its readers. Often the Indian Opinion's coverage emphasized how colonialism affects the socio-political conditions of Indian communities in Kenya. It will be significant to track any changes, throughout the decade, to the Indian Opinion's "Kenya Letter", and its coverage of colonialism in East Africa.

One key theme that resurfaces within the Indian Opinion's coverage of Kenya during this period is the desire for interracial cooperation and the building of IndianAfrican alliances in order to challenge the Kenya colonial authorities. In February 10, 1950, the newspaper's weekly column "Kenya Letter", describes the outcomes of a legislative push to form an 'African Federation'. Through the re-organizing and consolidating of political positions in the colonial settler/subject relationship, the 
establishing of an 'African Federation' would, in view of Indian Opinion's coverage, further marginalize the representation and interests of Kenya's Indian and African communities. The article observed:

"The motion, which was adopted in the teeth of Indian and African opposition, [14 Europeans voted in favour and 7 Asian and African Members against], was in amended form and will now restrict to matters of defence and communications between East and Central Africa... In an outspoken address, the Indian member of the Assembly, the Hon'ble A.B. Patel [Indian Congressmember in Kenya], strongly attacked the motion of Sir Alfred Vincent [British settler in East Africa]. Mr. Patel declared that the non-European population was vehemently opposed to any step which would bind them closer to the South where racial discrimination existed in a vastly greater degree." 36

During colonialism, swaths of European immigrants flooded 'Settler states' such as Kenya and South Africa in order to exploit and secure land which they deemed vacant or not being used adequately in regards to the formation of a colonial state. The establishment of an African Federation, in January 1950, across nations in East and Central Africa was viewed as a colonial gesture that aimed to unify political demands of settler populations across regions, a move which would further diminish the political influence of indigenous populations whom already lacked equal representation on local councils. The establishment of 'African federations' in Kenya, thus, was an effort of political authoritarianism, by a colonial government who had guaranteed cheap sources of land and labor to its European settlers and who needed to politically ascertain such resources in the face of fierce economic competition by the Kikuyu. In the long run, it would become evident that Africans in Kenya had nothing to gain from participating in

\footnotetext{
${ }^{36}$ Manilal Gandhi, \& Natal Phoenix, "Indian Member Attacks Motion" Indian Opinion,
} Feb. 10, 1950. 
the labor 'recruitment' strategies of the colonial government, as these strategies would only benefit the settlers. ${ }^{37}$

The paper contained a report from A.B. Patel, an honorable, elder member among the Kenyan Indian councilmembers, who claimed that the legislature would diminish the political influence of both Asian and African Kenyans, and which illustrates the nuanced intersections of the political interests between these two racial groups. Additionally, Patel's connection of the racialist policies of the colonial state in East and Central Africa to the racialist policies of settlers in South Africa displayed linkages in the colonial experiences of diasporic Indians whom, in the 1950s, had already established substantial communities in South, Central and East Africa. Indian Opinion's emphasis on a united opposition among Indians and Africans in Kenya illuminates the paper's desire, along with significant percentages of Indians in Kenya as well as South Africa, in creating a unified front against British colonial rule. In doing so, it was hoped that the Indian minority in both locales would not be ignored by the Kenyan and South African majority or by the white-dominated government opposition.

Indian Opinion's “Kenya Letter" continues the discussion of African and Indian political unity in Kenya, by documenting the advocating of reforms to the Tanganyika Legislative Committee, which would necessitate equal representation of Africans in colonial Kenyan governments and legislative committees. ${ }^{38}$ The establishment of the Tanganyika Legislative Committee, in January 1950, equaled the formation of a

${ }^{37}$ Caroline Elkins, Imperial Reckoning: the Untold Story of Britain's Gulag in Kenya, New York :Henry Holt and Co., 2006, pp. 22-23

${ }^{38}$ Manilal Gandhi, \& Natal Phoenix, "Tanganyika Indians Support Reforms”, Indian Opinion, Apr. 28, 1950 
representative body that advanced the interests of colonial administrators upon indigenous and settler populations in Kenya. Economic privilege and power were maintained through the uneven distribution of representation in the Tanganyika Legislative Committee, as it passed laws and regulations which restricted the ability of African producers to compete with settler farmers and merchants. Thus, the reforms advocated by Tanganyikan Indians, who also supported the political interests of the indigenous in Tanganyika, were viewed by the colonial state as a threat to European settlers in Tanganyika. Indian Opinion's coverage of the unified support for reforms to the Tanganyika Legislative Committee emphasizes the notion that political solidarity among Kenya's African and Indian communities was present and actively functioning to denounce practices of colonial domination. Also, the coverage indicates Indian Opinion's desire to reveal the ways in which interracial, anti-colonial solidarity among Asians and Africans in East Africa threatened the political interests of settlers, the 'pawns' of the British colonial agenda in East Africa.

The paper also describes the advocation of reforms on behalf of African and Indian Communities in Kenya, combined with the hosting of a joint conference for Asiatic and African women in Kenya which served to "assist in bringing about closer contact and understanding" between Asian and African Kenyan women, boasts a great communal effort on behalf of both communities in creating a shared body politic that promotes the interests of "Non-Europeans" in Kenya. ${ }^{39}$ Indian Opinion, thus, was not only concerned with the reporting of political ties among Kenya's Indian and African

\footnotetext{
${ }^{39}$ Manilal Gandhi, \& Natal Phoenix, "East African Asian Women Organize", Indian Opinion, May 9, 1950
} 
communities but also, the reporting of social bonds and community formations. Indian Opinion viewed a shared sense of political and social identity among Indian and Africans to be necessary for resisting colonial constructions of racial division in South Africa and Kenya. The establishment of colonial legislative councils and committees in Central and East Africa, which favored Indians and further displaced Africans in the regions, were interpreted by the Indian Opinion as the advancing of racial divisions resembled in South African racialism. ${ }^{40}$

South African Indians could viscerally remember and identify with the experience of colonial domination through the establishment of councils who privilege settler communities. As subjects to a vicious apartheid racialism, a consequence of settler domination and colonial conquest, readers of the Indian Opinion were encouraged to envision how the very practices they fought against in South Africa, were also impacting African and Indian communities in East Africa.

Additionally, the coverage may reveal Indian Opinion's agenda in showing how the making of inter-racial coalitions was crucial in Kenya's resistance to colonial rule, as it would convince more South African Indians to consider the significance of establishing inter-racial coalitions in resistance of apartheid in South Africa. This revelation in the paper displays a subtle way in which Manilal Gandhi's anti-colonial vision differed from that of his father, Mohandas Gandhi. Manilal recognized that the political advantages of principled non-violent resistance did not outweigh the violent consequences of imposing settler interest's onto African communities in Kenya. Therefore, Manilal's vision had a

\footnotetext{
${ }^{40}$ Manilal Gandhi, \& Natal Phoenix, "Non Europeans Condemn South African Racialism", Indian Opinion, May 23, 1950
} 
capacity to compensate principles of non-violent resistance with the political opportunities afforded by inter-racial, anti-colonial solidarity in East Africa.

Indian Opinion, in recognizing and exploring the unified political stances among Kenya's Indian and African communities, expresses the shared experience of all "nonEuropeans" in Kenya. Also, it contextualizes the socio-political climate of pre-Mau Mau Kenya through the drawing of similarities with South African racialism under apartheid. This contextualization of the socio-political climate of Kenya, leading up to the birth of the Mau Mau uprising, indicates that the Indian Opinion was not merely interested in how colonialism was affecting Kenya's Indian community, but also, Kenya's African community. The emphasis upon the connection between South African racialism and the advancing of settler interests in political councils in East Africa is significant to highlight as it indicates a shift in the reporting of the Indian Opinion, from a focus on the colonial plight of Kenyan Indians to a focus on the colonial violence of the British colonial regime and its impact on Kenyans and South Africans.

By portraying the colonial establishment of councils and committees in East Africa and Central Africa during the 1950s, as the advancing of South African racialism to East and Central Africa, Indian Opinion's interpretation of the growing struggle for political equality and liberation in East Africa calls into question a continental dispute between settlers and the indigenous. In the shifts of emphasis from the national and the regional, to the continental, Indian Opinion urged South African Indians to re-consider their plight against apartheid and Kenya's plight for national independence, as one plight against European imperialism on the African continent. Manilal Gandhi and the Indian Opinion were actively involved in re-constructing the colonial narrative in East Africa, 
illuminating the similar forms of racial discrimination present across European imperialism in Africa, while engaging the violent manifestations of imposing settlerbased colonial rule, specifically, in 1950 East Africa. Moreover, this reconstruction makes inter-racial, anti-colonial vital in responding to European imperialism in South, Central, and East Africa.

Indian Opinion's continued coverage of British colonialism in Kenya leading up to and at the start of the Mau Mau uprising describes a political assault on all non-British colonial subjects of Kenya. A 1951 "Kenya Letter" column records two specific resolutions that would seek to enact the arguments of Kenya's Britons in the legislature. The arguments stipulate that the only ruling party of the state is the British colonial regime, and further, that only the vision of the colonial state can advantage indigenous peoples in East Africa. The passage as titled by the Indian Opinion, contends that Kenya's Britons advocated 'white-rule' of East Africa:

"We the British inhabitants of Kenya contend that the Government of the United Kingdom has no right to share the rule of Kenya with any other immigrant people other than resident Britons without the express consent of the coastal Arabs and the Tribes... That no person who is not ever a citizen of the United Kingdom...or alternatively has not by specific personal oath sworn allegiance to the King should be allowed any direct or indirect say in the central affairs of Kenya... It is essential we make it perfectly clear to everyone that Indian immigration on the grand scale is a menace to the African". ${ }^{41}$

British settlers in Kenya, expanding upon power-control legislature in East Africa, argue that they should be the sole governors and political practitioners of colonized Kenya. This form of consolidation of the colonial state, through the squashing of political

${ }^{41}$ Manilal Gandhi, \& Natal Phoenix, "Kenya Whites Want Britons Alone to Govern" Indian Opinion, Jul. 20, 1951 
representation of colonial subjects, was an act of defense brought forth by the ending of the World Wars. The consolidation of settler power in colonial states occurred in varying European colonies across the continent, as European colonies attempted to recover from the economic crises caused by the World Wars, particularly World War II. ${ }^{42}$ The outcome of these power consolidations in colonial states is an increased pressure for Africans to accept political incorporation with the colonial state, and in that incorporation, to break inter-racial ties in the anti-colonial agenda of Asian and African Kenyans.

As perceived by Indian Opinion, this event signifies the beginning of a complete functional deterioration of British colonial rule in Kenya, as a last-ditch effort to grasp power is made through the advancement of colonial control which usurps the political say of Kenya's African and Indian communities. The unpredictable lashing out of the colonial state at all colonial subjects was exactly the event Indian Opinion needed to justify a re-interpretation of Indian and African political unity in Kenya as viscerally necessary in resisting European domination of colonial politics in Kenya.

Other tactics of colonial regimes seeking to consolidate settler power, such as the division of its subjects through religious, ethnic, and other means are observed in Indian Opinion's reporting of the beginning of 1952, when legislature proposed to divide Muslim and non-Muslim Indians by categorical separation of religion at electoral polls was starkly rejected by African and Indian council members. ${ }^{43}$ The African council members' willingness to engage the political concerns of East African Indians, Muslim

\footnotetext{
${ }^{42}$ Caroline Elkins, Imperial Reckoning: the Untold Story of Britain's Gulag in Kenya, New York :Henry Holt and Co., 2006, pp. 24

${ }^{43}$ Manilal Gandhi, \& Natal Phoenix, "Separate Electoral Rolls in Kenya”, Indian Opinion, Jan. 11, 1952
} 
and non-Muslim, coupled with A.B Patel's attacking of the 'African Federation' in 1950, indicate that bonds of inter-racial solidarity among Indians and Africans in Kenya were benefiting the anti-colonial aims of both communities. Similar cross-racial, political unity occurred just a month later when African and Indian Kenyans staged massive protests in Nairobi against South Africa's apartheid regime. ${ }^{44}$ Indian Opinion's coverage of the building up of political resources aiming to increase inter-racial solidarity among African and Indian communities, thus, totally rejected the colonial interpretation of a 'menacing' Indian presence among the political concerns of indigenous East Africans.

While settlers and colonialists in Kenya wished to produce an image of control, viability, and productivity regarding their colonial activities, Indian Opinion emphasized a perspective which was centered in the East African colonial apparatus's marginalization of the needs of Indians and Africans in Kenya. This exclusion signified the very real, inadequacy in the colonial state's capacity to produce political stability, a factor which in the view of a significant branch of British liberal economists and politicians of the time, created risks for the colonial regime itself, and would justify an ending of colonial practices. Indian Opinion presented settler colonialism in Kenya as unstable and set a unique precedent in which revolution could be viewed as not only internally necessary but entirely inevitable.

By 1952, Indian Opinion's coverage explored reports upon the political outlook of a seemingly inevitable anti-colonial revolution in Kenya and presents emerging discussions on the socio-political reasonings for which Indians in Kenya would join

\footnotetext{
${ }^{44}$ Manilal Gandhi, \& Natal Phoenix, "Kenyan African and Indian Support", Indian Opinion, Feb. 29, 1952
} 
African Kenyan's resistance of colonial rule. The emergence of these particular discussions proved timely as the Mau Mau uprising was just months away. Indian Opinion's coverage during this lead up focused on the consequences of European colonial rule in Kenya as well as the dismissal of African and Indian political representation. R.M Desai, a South African Indian journalist and editor who collaborated with the Indian Opinion, visited East Africa and discussed his findings in the newspaper.

"One can also foresee that the present trend of events must lead to a situation when the Europeans, Indians and Africans will have to find a way of working together in co-operation for the purpose of evolving a suitable constitution to achieve self-government. That cannot be done unless the European community abandons its insistence upon retaining dominant power in its hands," he noted. ${ }^{45}$

In doing so, Desai argued that political co-operation among settlers, immigrants, and the indigenous populations was necessary if Kenya were to move towards self-rule and potentially independence. In his opinion, however, the white British settler community's insistence on a privileged existence prevented such co-operation from occurring. Desai's envisioning of improving the political wellbeing of Kenya necessitated the complete retraction of colonial control and settler domination. Indian Opinion, in the coverage of Desai's findings, presents a radical view of the viability of colonialism in Kenya, encouraging its readers to question how long colonialism could continue to exist in East Africa.

Before the onset of the Mau Mau uprising, Indian Opinion was contextualizing the colonial struggles for power between settlers and indigenous communities in Kenya, within a larger struggle for political wellbeing and freedom of indigenous populations in

\footnotetext{
${ }^{45}$ Manilal Gandhi, \& Natal Phoenix, "My Impressions of East Africa", Indian Opinion,
} Jun. 6, 1952 
South, Central, and East African colonies. Early on in the decade, Indian Opinion's coverage focused on understanding how colonialism was affecting various communities in Kenya. In emphasizing the Indian experience in Kenya, the newspaper's coverage focused on the mutual interests and growing social bonds between Africans and Indians within the colony. The Indian Opinion's perspective upon colonialism in Kenya was driven by the outcries of a distressed colonial regime whose primary function was to claim political power for its settler class. On the eve of revolution, Indian Opinion's coverage stressed the necessity of continued political collaboration between African and Indian Kenyan communities in the face of aggressive colonial legislature.

Aggressive, colonial retaliation on behalf of such collaborations or their political activities would indicate just how threatened the colonial state had become. Indian Opinion was no longer primarily concerned with colonialism in Kenya as it affected its Indian community, it was equally concerned with the colonial domination of indigenous populations. This particular shift would be the initial effort of the Indian Opinion to encourage its readers to understand the political revolution in Kenya and the Mau Mau, as a necessary starting point towards a liberated Kenya. By the time the Mau Mau had set under way, and revolution was visible to the world, Indian Opinion had approached its readers with a rich understanding of the social and political mechanisms of the colonial state in Kenya. The precedent for the Mau Mau was set. 


\section{South African Indian Interpretations of the Mau Mau Uprising}

By 1953, Indian Opinion observed the Kenyan colonial situation as completely dissolving into violence. To express the complete political disarray, Indian Opinion reports thousands of Kikuyu women protesting to the British Queen, upon the brutal conditions of a martial law imposed by the colonial regime in order to quell anti-colonial activities. According to the report, "women were so afraid of Native Police that they slept in the bush with their children... Children were forced into famine as a form of collective punishment by the British empire... The government began to massively close schools". ${ }^{46}$ It was in the most volatile social conditions which Kenyan women were protesting to the Queen of England, and if their calls would not be heard, they could no longer accept British rule as merely ignorant or dismissive of their concerns, rather they came to accept it as an active and violent political staging against the African people.

The British empire sensed revolution was near and began punishing civilians, including their children, through the tactics and methods of martial law practices in a colonial setting. It is significant to note that in the first reporting of violence between the Kikuyu and colonial police, Indian Opinion interprets the growing political violence in Kenya as colonial punishment of innocent civilians, rather than, an outburst of anticolonial 'terrorism' as colonial forces would late describe. It was under these social conditions that Jomo Kenyatta and other leaders among the Mau Mau were arrested, and it was likely these events that reaffirmed the suspicions of readers of the Indian Opinion

\footnotetext{
${ }^{46}$ Manilal Gandhi, \& Natal Phoenix, “Thousand Kikuyu Women Petition Queen”, Indian Opinion, Mar. 6, 1953
} 
of the ethics of British colonial rule in Kenya. ${ }^{47}$ As the revolution was beginning to unfold, the Indian Opinion's coverage emphasized the brutal measures being taken by the colonial forces and the British Empire. As such, the Indian Opinion articulated that colonial responses of police brutality and the enforcement of martial law would only further justify the existence of the revolution.

Indian Opinion urged its readers to interpret the colonial situation in Kenya from the perspective of the Africans who have had diminishing holdings on land and thus, experienced severe economic loss. An August 1953 report provided a meaningful social context to the Mau Mau revolution: “To understand Mau Mau you have to know something of the history of the country: you have to be able to feel what it is like to be an African, treated as an inferior in your own country, confined to the smallest of inadequate small-holdings while one European is granted thousands of acres". ${ }^{48}$ In connecting the experience of land conquest by settlers and colonial states to the diminishing political mobility of the African in colonial Kenya, Indian Opinion emphasized the manner in which the Mau Mau uprising was capable of restoring justice in an unjust colonial society while articulating experiences that viscerally resonated with the paper's South African readers. Instead of condemning the violence, the Indian Opinion presented the Kikuyu claims as worthwhile or legitimate in view of the Mau Mau uprising. In every sense, the colonial apparatus of Kenya was dividing and punishing its subjects, and using violence to enforce any social change which the legislature could not. Thus, two years into the

${ }^{47}$ Manilal Gandhi, \& Natal Phoenix, “Another Kenya African Member Arrested”, Indian Opinion, Mar. 13, 1953

${ }^{48}$ Manilal Gandhi, \& Natal Phoenix, "Startling Story of Mau Mau”, Indian Opinion, Aug. 7, 1953 
birth of the Mau Mau, Indian Opinion was examining the violence of the British colonial rule and invoked a more resolute understanding of and deeper sympathy towards Mau Mau revolutionaries and the communities of people they represented in their freedom struggles.

In revealing the manner in which the colonial regime misconstrued the goals, activities, and outcomes of the Mau Mau, Indian Opinion displays a substantial effort to correct perceptions about the cause and scope of colonial violence in East Africa. In light of those revelations, Indian Opinion emphasizes the function of satya, or truth principle, within Gandhi's political philosophies of satyagraha, proposing an alternative conceptualization of the Mau Mau's violence which illuminates its responsive nature to the violence of the British colonial regime. Therefore, Indian Opinion's interpretation of violent East African colonialism conceives of the Mau Mau uprising as a movement of self-defense of the Kikuyu and other colonized peoples in Kenya, and in turn, highlights ideological commonalities between the anti-colonial activism of the Mau Mau uprising, and that of Gandhi's satyagraha campaign in the Indian Diaspora.

Throughout its coverage, Indian Opinion identified the goals and interests of the Mau Mau uprising, and articulated support and solidarity with the Kenyan independence movement. Support of the Mau Mau, in the face of a complex and powerful colonial apparatus which actively misconstrued its engagements with Mau Mau, reflected an understanding of what it meant to be an African in colonial Kenya, where innocent civilians labeled as terrorists or vigilantes were subject to colonial arrest. Thus, as the revolution grew on, Indian Opinion emphasizes how the Mau Mau served to exert 
pressure on the colonial state, while never becoming what the colonial state would have it appear to be: a genocidal movement against Europeans in East Africa.

Beyond stressing the legitimacy of those resisting colonization in Kenya, the Indian Opinion emphasized the colonial institutions, such as colonial government and police, as the primary combatants and promoters of violence against subjugated citizens. In mid-January, 1954, the Indian Opinion depicted just how violent and socially destructive the Kenyan 'Home Guard' had become and observed,

"In their meetings the Home Guards jot down list of names of those whom they want to kill, take it to show the district officer who gives them a motor-car at night, and then they fetch every man from his home, put them in the car and then shoot them... Some of the bodies they take to Kiambu and in the morning they are said to be terrorists". 49

The lack of transparency in this vigilante police work, combined with its vicious outcomes, mirrored the methods of governments notorious for genocide. Additionally, the indiscriminate attribution of the terrorist status to civilians not only indicated the failure of the police to produce justice but also, revealed the colonial government's terroristic capacities and wanton use of violence.

Nearly a month later, the Indian Opinion reported increased levels of police violence in Kenya and even compared it to that of Palestine, where civilian populations are similarly policed and brutalized:

"In such circumstances- in Kenya, as in Palestine- things are said and done by individuals which are neither nice nor fairly represent majority opinions. But when- as recently in Palestine and now in Kenya- this sort of infectious brutality

${ }^{49}$ Manilal Gandhi, \& Natal Phoenix, "Mau Mau Movement in Kenya.” Indian Opinion, Jan. 15, 1954 
invades the regular armed forces, which are supposed to be under strict disciple in peace or war, then it must meet with unqualified condemnation". ${ }^{50}$

The connection to Palestine is significant as it speaks to the violence required in the enforcing of settler colonialism across the globe. Through this coverage, European settlers were viewed as dominating territories with no regard for the indigenous people of these places. The police were viewed as the only firm security in this matter, whether in Palestine, South Africa, or Kenya. Further, Indian Opinion's coverage emphasizes how condemning police violence is imperative to people of color, around the globe, in the function of anti-colonial activism during the mid $20^{\text {th }}$ century

Indian Opinion, concluding its magnified coverage of policing, reports on a disputing of the justice-producing ability of the Kenyan colonial police forces by the Kikuyu. The newspaper reads: "The Government of Kenya has not succeeded sufficiently in rallying the mass of the Kikuyu to the side of law and order. ${ }^{51}$ Indian Opinion depicted the Kenya colonial government as reliant upon a growing police force that displayed an inability to produce justice, civility, and peace. Beyond that, the newspaper intimated that Kenya was transforming into a police-state that sought to violently punish civilians through military and police force and extra-judicial means (i.e. vigilante violence). Therefore, the Kenya colonial police were depicted as a mechanism of the colonial agenda that only intensified East Africa's political instabilities.

\footnotetext{
${ }^{50}$ Manilal Gandhi, \& Natal Phoenix, "Kenya Court Martial” Indian Opinion, Feb. 12, 1954

${ }^{51}$ Manilal Gandhi, \& Natal Phoenix, "British Parliamentary Delegation On Mau Mau", Indian Opinion, Mar. 5, 1954
} 
On April 2, 1954, the Indian Opinion published an opinion piece entitled "African Viewpoint: Developments in Kenya" by Jordan K. Ngubane, an African scholar on Zulu society and culture, and an editor of the predominantly African newspapers The Natal Sun, Bantu World, and Bantu Forum. ${ }^{52}$ In his essay, Ngubane called out Indian Kenyans for being too passive in their resistance to colonialism, and he condemned the Indian Kenyans for not advocating for proportional racial representation in the Kenyan Senate, which Ngubane claimed disproportionately hurt Kenya's African populations. Beyond assigning blame to this population, Ngubane argued that the division between Indians and Africans in Kenya was the result of a deliberate strategy enacted by the colonial state. Ngubane expresses doubts about the Indian's willingness to resist such a strategy, especially when the outcomes would benefit Indian Kenyans. Finally, Ngubane questions the depth of political solidarity among Indian and African communities in Kenya. Citing an African writer in the Indian Opinion who brings controversy to the actions and views of Indian Kenyans illustrates a refusal to ignore the plight of the African in a colonized Kenya.

In publishing Ngubane's piece, Indian Opinion went beyond a refusal to ignore the African viewpoint, and instead, forced the paper's readers to acknowledge that Indian Kenyans were making ambiguous their efforts to promote an inter-racial anti-colonialism in East Africa, and brought to attention the way in which Kenya's Africans were interpreting the disruptive outcomes of the recent anti-colonial efforts of Kenya's Indians. Additionally, Indian Opinion's reporting on the 'passive resistance' of Kenyan Indians

\footnotetext{
52 Manilal Gandhi, \& Natal Phoenix, "African Viewpoint: Developments in Kenya" Indian Opinion, Apr. 2, 1954
} 
and its inadequacy in resisting active British East African colonialism is relevant to Gandhi's tapasya principle, which advocates active anti-colonial resistance through the sacrifice of one's self pleasures. In revealing how 'passive resistance', from the viewpoint of the African, acted as a refusal to sacrifice colonial privileges offered to Kenyan Indians by the British colonial regime, the reporting of the Indian Opinion serves as a call for change in the anti-colonial activism of Kenyan Indians.

Throughout the period of revolution, Indian Opinion focused on the institutions within colonial societies who enact violent racialism upon innocent citizens, and, critically reflects on the recent politics of Indian Kenyans, admonishing them for negotiating with colonial forces without respect to the cause of the African community. This critical reflection is particularly interesting as it would suggest that South African Indians were more racially progressive in politic than those of the Indian Kenya diaspora, despite their philosophical orientation in Gandhi's principles of satyagraha as a platform for non-violent political action. Rather than viewing the Mau Mau uprising as a violent articulation of indigenous Kenyans whom needed to be controlled through colonialism, as some Indian Kenyans very well did, Indian Opinion and its audience interpreted the Mau Mau as an inevitable response to a violent and unstable colonial regime. In this reframing, Indian Opinion's coverage strips power and influence from colonial interpretations of the Mau Mau through an acknowledgment of how East African nationalisms were inclusive of the socio-political needs of the colonized in Kenya.

Viewing deteriorating political conditions as a result of the British colonial government's terroristic response to the Mau Mau, Indian Opinion's coverage of Mau Mau proved more sympathetic to this African anti-colonial movement than newspapers in 
Europe. the reporting of the Indian Opinion focused on activities of the colonial state and the police, and their punishment of civilians and children through the enactment of practices of martial law, such as night raid arrests and para-military intervention in communities. Indian Opinion supplemented this reporting with the publishing of opinion pieces who sought to widen the perspectives of readers away from a focus on Kenya's Indian community, and towards a focus on the indigenous populations in Kenya, who were most egregiously impacted in the course of Kenya's violent colonialism.

Additionally, as opposition to colonial mechanisms in East Africa grew, the instability of the colonial regime triggered a diminishing of democratic rights and free political life for colonial subjects. The political precedent for the Mau Mau was set before the uprising started, but it was during the uprising itself when the Indian Opinion became most concerned with its ideological justifications relevant to a global discourse of anticolonialism and resistance to colonial conquest. The newspaper seems to not celebrate Mau Mau violence so it doesn't contradict Satyagraha principles, and instead, it focuses on demonizing state violence and articulating how that is a more crucial aspect of political instability in Kenya.

\section{South African Indian Perceptions of the Colonial Response to the Mau Mau Revolution}

By 1955, the Indian Opinion's focus shifted to the issues of land rights and settler domination in Kenya, two topics with parallels to the experiences of Indians and Africans in South Africa. The segregation of indigenous populations in colonial states and the conquest of native lands are a key political interest of settlers, and in producing "land 
hunger" among indigenous populations, serve to disadvantage indigenous populations. This point could not be emphasized enough; in the Kikuyu culture, the land was life. In order to become an adult, whether male or female, the rite of passage in Kikuyu culture required the ownership of land. While the British colonial government justified instances of land segregation through the rise of epidemics and famines in areas given to settlers, the Kikuyu peoples were increasingly cornered into reservations and labor camps, and off of their land.

Indian Opinion publishes a piece in April, 1955, by John Seymour, a British writer who served in the King's African Rifles in Kenya, which emphasizes pleasant race-relations in Kenya, the intellectuality of Jomo Kenyatta and other described leaders of the Mau Mau, the religious fervor of the Mau Mau and its appeal to the Kikuyu people, as well as a multi-racial Kenyan society and culture. Seymour's account presents a mixed perspective on colonial and anti-colonial events in Kenya which makes meaningful, and controversial claims on behalf of both the outcomes of British colonialism and the Mau Mau uprising. While Seymour justifies land segregations in Kenya through the typical colonial discourse of epidemic and famine, he does seem to identify the colonial government as the reason for land hunger in Kenya, which could be interpreted as a fairly remarkable view for a writer who served in the King's African Rifles. At the end of the section, Seymour writes:

"I believe that in ten years time there will be no land hunger in Kenya. And I believe that there will be very much better relations between the different races there. And I believe that it will have been the shock of the Mau Mau rebellion that will have brought these things about" (Indian Opinion, "The Mau Mau Brings New Spirit to Kenya", Apr. 1, 1955). ${ }^{53}$

\footnotetext{
${ }^{53}$ Manilal Gandhi, \& Natal Phoenix, "The Mau Mau Brings New Spirit to Kenya”, Indian Opinion, Apr. 1, 1955
} 
In asserting that the Mau Mau's success would bring about these monumental reforms, Seymour is essentially articulating the worthiness of the rebellion itself. This articulation is, if nothing else, wholly surprising given that the mainstream British view of the Mau Mau in 1954, just a year prior, characterized it as a genocidal movement which threatened Kikuyu and Europeans alike. Seymour is specific when using the phrase "the shock of the Mau Mau Rebellion' as if the revolution will reveal, or bring to light, something fundamentally unstable, or not viable, in the colonial state of Kenya. The term shock also can be interpreted in regards to the violent change which revolutions aspire to produce. Thus, Seymour acknowledges that first, revolution was necessary for liberating Kenya, and that second, revolutionary change would have to disrupt and confront the violence of the colonial state. Indian Opinion not only emphasizes the inevitability of political change as a result of the Mau Mau uprising but reversely, envisions the manner in which the revolution would enforce a dissolution of the colonial state in Kenya, for the viability and productivity of the people living there.

In late September 1955, Indian Opinion published a book review which exposes a false narrative regarding colonial and anti-colonial violence, based on inaccurate statistics of victim counts in Kenya:

"The news from Kenya has been- and still is- so badly distorted that many readers imagine that tens of thousands of white people have been killed. In fact, however, since violence began there, fewer than fifty Europeans have been killed. In return the number of Africans killed is 150 times, yes, 150- as great, i.e. over 8,000" (Indian Opinion, "The Struggle for Kenya", Sep. 30, 1955). ${ }^{54}$

\footnotetext{
${ }^{54}$ Manilal Gandhi, \& Natal Phoenix, “The Struggle for Kenya”, Indian Opinion, Sep. 30,
} 1955 
By the end of 1955, Indian Opinion seemed more focused on telling the story of the Mau Mau from the African perspective in Kenya and less focused on the perspective of the Indian Kenyan. This shift in perspective of coverage, as evidenced by a full year without reporting on colonialism as it relates to Indian Kenyans on the Mau Mau, illustrates the effort of Indian Opinion to correct the narrative for its readers by emphasizing what the African perspective in Kenya is, rather than relying on how the colonial government portrays it. Colonial states depended on the pervasiveness of the European global press to inform the description of conditions of violence. In highlighting the distortion of the situation by the colonial state, Indian Opinion forced its readers to acknowledge the British government's general lack of concern for human wellbeing in Kenya. Through the Indian Opinion's coverage of the Mau Mau and the colonial response to the Mau Mau, the newspaper's interpretation emphasized how colonialism was at the heart of the exploding political situation and its violent manifestations. Thus, incorporation with the colonial state, and participation in a system where settlers competed with indigenous populations was no longer an acceptable avenue of a political resolution in East Africa.

Indian Opinion's continued interest in colonial responses to the Mau Mau continued throughout the decade, and the paper presented the conflict as a bilateral war, one war fought by politicians and lawyers in day time court-rooms and one war fought by police and freedom fighters, where night-raid arrests and outbursts of violence occurred regularly. The first layer of battle received coverage from Indian Opinion in December 1957, which detailed the struggle for African Kenyans to achieve equal representation in government systems in Kenya, as constitutional resolutions were passed to limit the influence of African and Asian councilmen in Kenya. African councilmen in Kenya were 
threatened by the British with a package of legislation, which, while giving more direct seats to the African community, would act to preserve settler privilege in the congressional setting by creating a stipulation which allowed European council members to veto democratically elected African/Asian members of the council. This strategy was denounced and rejected, in the form of boycott, which in turn, led to their eventual arrest. $^{55}$

Presenting a new level of settler control in the congressional setting, under the visage of a compromise towards the interests of colonial subjects, was an act of direct advancement for settlers. Constitutional resolutions and the 'compromises' held within were of "little say" to council members who rejected them, as all the council members who rejected the measure were arrested. Thus, Indian Opinion presents the first battleground as the formation of the colonial political agenda in the legal setting and illuminates the strong-arming of anyone who was determined to defy their coercing. This narrative also indicates how pervasive violence had become in the methods of the colonial state in controlling the political atmosphere in Kenya, and Indian Opinion would not hesitate to bring that to the forefront of the reader's attention with a headline article.

The second layer of battle revealed that arrests on behalf of the Kenyan police force were increasing in quantity and in severity. Indian Opinion detailed the arrests of over 80 Kikuyu peoples and 7 African Kenyan Council Members over a period of two weeks. ${ }^{56}$ This report illustrates the indiscriminate arrest of civilians and council members

${ }^{55}$ Manilal Gandhi, \& Natal Phoenix, "Kenya Africans Reject New Plan to Increase Representation”, Indian Opinion, Dec. 13, 1957

${ }^{56}$ Manilal Gandhi, \& Natal Phoenix, "Kenya”, Indian Opinion, Feb. 21, 1958 
suspected in engaging with the activities of the Mau Mau. This continued focus on the brutal extremity and indiscriminate, terroristic nature of the colonial response to the Mau Mau in many ways, taps into the 'Satya' principle of truth, where the South African Indian can interpret the colonial response as actively destructive, and morally inadequate. The perspective and focus are what ultimately emphasize South African Indian support for active resistance in Kenya, and recognizing the Mau Mau uprising as a grave condemnation of British colonialism in Kenya and its consequences on the African Kenyan.

Responses to the revolution subsume the remainder of Indian Opinion's reporting on colonialism in Kenya during the decade. Violent intervention from the colonial state, on behalf of its police, are both shock-producing, and an intense reminder of what was at stake for civilians in Kenya. Emergency resolutions, which included curfews, communal punishments, and indiscriminate night arrests, were utilized frequently by the British colonial government in order to maintain control. This process, viewed as a delirious attempt of the British colonial government to force the Mau Mau into submitting to authority, only strengthened Kikuyu oath taking to the Mau Mau.

The violent interventions, thus, seemed to only further eliminate any moral quandaries of the readers surrounding the idea of revolution, as revolution was the only way to disrupt the moral evils that were preserved by the colonial state in Kenya. The terroristic capacity of the colonial state, in the advancing of its political agenda by day, and the subduing of its political opponents by night, monopolized the attention of Indian Opinion and its readers. By the turn of the 1960s, the colonial state appeared completely reliant on political subordination and intimidation of in order to function. As the Indian 
Opinion would record, the Mau Mau forced the colonial state to clarify its purpose and function in Kenya's political, economic and social, and when it did clarify its purpose, the agenda of the colonial state revealed its violent nature.

\section{Gandhi's Influence: Jomo Kenyatta and the Mau Mau}

In determining Indian Opinion's interpretation of Mohandas Gandhi's influence on the Mau Mau revolution and Jomo Kenyatta, it is necessary to contextualize the role of non-violent resistance in resisting colonial oppression, specifically in East Africa. Gandhi describes the socio-political function of non-violent protest as a process which utilizes the moral leverage of any oppressed group of people, however, he does not endorse it as an effective methodology for deterring colonial violence. To emphasize this point, Gandhi contends that the ability of non-violent protest to persuade colonial actors is predicated on the existence of colonial violence. Thus, while the moral shaming of colonial violence is a fundamental goal of non-violent protest, the direct rejection of colonial violence, is not a necessary outcome.

In the context of violent colonial oppression in East Africa, Jomo Kenyatta and the Mau Mau revolution were tasked to not just reveal the moral implications of colonial violence, but to also protect the Kikuyu people from imperialism's brutal consequences. In Defeating Mau Mau, Creating Kenya: Counterinsurgency, Civil War, and Decolonization, Daniel Branch examines the brutal violence that Kenya's "Home Guard" 
exacted upon the Kikuyu people. In doing so, Branch reveals the nuanced entanglements between violence by the colonial regime and the violence of the Mau Mau fighters. ${ }^{57}$

Rather than arguing that Gandhi's political philosophies of non-violence had a forceful impact on a violent East African revolution, this study's analysis contends that in view of the Indian Opinion's coverage on the Mau Mau, violent revolution and its function was tied to the repression and disruption of colonial violence against the Kikuyu people. South African Indian readers of the newspaper were reconstructing their views of the nature, role and scope of colonial violence in East Africa in view of the Indian Opinion's thorough coverage. The shifting attitudes about Mau Mau activism and colonial violence observed by Indian Opinion's coverage displays that its South African Indian readership offered alternative conceptualizations of satyagraha which emphasized the 'Truth' philosophy before the 'non violence' in the context of violent revolution in Kenya. This process inculcated an understanding of why the violence of the Mau Mau revolution was necessary in not only combatting, but revealing, the atrocity of colonial violence, and how this process was imperative to obtaining Kenya's freedom.

Indian Opinion's coverage, therefore, illustrates the cost of dismissing violent socio-political disruption as a non-viable method to protect the subjects of East-African colonialism: continued European settlement of Kikuyu lands, terroristic policing of Kikuyu families and communities, and repression of the needs and interests of the

${ }^{57}$ Daniel Branch, Defeating Mau Mau, Creating Kenya : Counterinsurgency, Civil War, and Decolonization, Cambridge: Cambridge University Press, 2009. Other scholars have examined similar aspects, see Kinuthia Macharia and Muigai Kanyua, The social context of the mau mau movement in Kenya (1952-1960), University Press of America, Lanham, Md, 2006 
Kikuyu people. Despite Indian Opinion's coverage of the similarities between the colonial experiences of anti-colonial Indians and Africans in East Africa, Indian Opinion emphasized the notion that colonial oppression often had disparate consequences across its oppressed groups, urging South African Indians to acknowledge the shortcomings of Gandhi's philosophy of non-violence protest in producing a successful agenda of resistance to British colonialism in East Africa. 


\title{
CHAPTER 3
}

\section{INTERPRETATIONS OF GHANAIAN INDEPENDENCE IN INDIAN}

\author{
OPINION: 1950-1960
}

\section{Background to the Ghanaian Independence Movement}

Similar to the origins of British East African colonialism, British Gold Coast colonialism began in the 1880 s at the conclusion of the $1884-1885$ Berlin Conference. ${ }^{58}$ In the early $20^{\text {th }}$ century, British Gold Coast colonialism was primarily concerned with the exploitation of Gold Coast labor markets and resources, utilizing superior military technology on land and sea to quell any disputes caused in their colonial conquest for natural resources and access to low-wage labor. ${ }^{59}$ An authoritarian Gold Coast colonial regime, backed by the wealth and power of the British empire, depended on the economic exploitation of Gold Coast labor markets in order to ensure an advantageous economic positioning for the colony's settlers. ${ }^{60}$

The growth and development of African nationalisms over the period from 19001930 brought important changes to the prospectus and function of anti-colonial movements in the Gold Coast. Members of the nationalist intelligentsia capitalized on the

\footnotetext{
58 Toyin Falola, Africa, Vol. 4, Carolina Academic Press, 2002, pp.4

${ }^{59}$ Ibid, pp. 5

${ }^{60}$ Ibid, pp. 6
} 
British colonial regime's paternalistic view of the African by endorsing cultural nationalisms, self-determination, and independence. ${ }^{61}$ Despite these developments, early African nationalisms in the Gold Coast were reformative, aiming for the gradual engagement and transformation of colonial institutions. ${ }^{62}$

Two events spurred the radicalization of anti-colonial resistance movements in the Gold Coast: the Italian invasion and occupation of Ethiopia in 1935, and the end of World War II. The Italian invasion of Ethiopia produced substantial anti-imperialist and anti-colonialist sentiments throughout Africa, and these sentiments propagated the financing of an armed Ethiopian resistance by members throughout the African Diaspora, including the Gold Coast. ${ }^{63}$ The end of World War II generated increases in the production of export crops and caused labor shortages, causing strikes and labor protests in various West African nations including Ghana, Nigeria, and French West Africa. ${ }^{64}$ These strikes illuminate the manner in which the Gold Coast working class became a significant political force, viewed as a credible threat to British Gold Coast colonialism in Ghana's mid $20^{\text {th }}$-century struggle for independence.

The 1950s and early 1960s were a time in which new senses of nationhood would be developed in continental Africa, evidenced by a movement of nations for independence and sovereign nationhood from colonial actors. In 1957, Ghana became officially independent through the political work of Kwame Nkrumah, an event which

\footnotetext{
${ }^{61}$ Toyin Falola, Africa, Vol. 4, Carolina Academic Press, 2002, pp. 8

${ }^{62}$ Ibid, pp. 9

${ }^{63}$ Ibid, pp. 12

${ }^{64}$ Ibid, pp. 13
} 
symbolized and gave embodiment to an independent West Africa. Additionally, Kwame Nkrumah is identified as an actor of colonial resistance whom: first, sought to actively de-colonize the political state and social order of Ghana, second, resonated deeply with the working-class struggle of Ghanaians living in colonialism through the politics of the Convention People's Party, and finally, invigorated a profound, Pan-Africanist fervor within his movement for Ghana's independence by relating the liberation of Gold Coast Africans to the independence of the entire continent. ${ }^{65}$

In discussion of the differences which lie between the ways that South African Indians experienced and resisted apartheid colonialism and the ways that Ghanaians experienced and resisted British Gold Coast colonialism, it is necessary to explore the nuanced colonial and anti-colonial functions of exploiting Gold Coast economies and labor sources, the forging of an anti-colonial, Pan-Africanist movement in Accra, and the role of authoritarianism in shaping Ghana's colonial and post-colonial politics. The following literature review, in examining the colonial exploitation of Gold Coast economies, the makings of a metropolitan Accra as a continental icon for anti-colonial Pan Africanism, and the role of political authoritarianism in colonial and post-colonial Ghana, illuminates the nuanced socio-political conditions of British colonialism which shaped the ideological and political formation of the Ghanaian Independence Movement.

Scholar Emmanuel Akyeampong traces the production of akpeteshie (local gin) in Ghana in order to illuminate how it symbolized and resembled popular culture, government resistance, and the struggles of the working class. Akyeampong contends that processes of urbanization and economic development in the Gold Coast produced a

${ }^{65}$ Toyin Falola, Africa, Vol. 4, Carolina Academic Press, 2002, pp. 38-39 
rural-urban migration pattern among men that would bring their varying cultures and lifestyles into contact. Akyeampong details the economic emphasis of massive urban immigration in Ghana, describing how discriminatory liquor laws would produce resentments among urban and rural laborers. Akyeampong writes: "Ironically, the colonial onslaught against akpeteshie heightened the relevance of popular culture as an interpretation of the exploited existence of workers in urban Gold Coast". ${ }^{66}$ Referencing the origins and meaning of the word akpeteshie in the Ga language, translatable to the term 'hide-out', production of the drink was secretive and something kept out of view of colonial powers, an aspect of the drink's popularity with which was increasing to be associated with government resistance. In response, the British government would outlaw and restrict distillation processes, criminalizing not only the male laborers seen as the face of the producers of the drink but families and communities who supported them. This response, in Akyeampong's findings, would qualify nationalist political championing of akpeteshie by the Convention People's Party as activities of anti-colonial resistance. Akyeampong concludes by discussing the evolving status of akpeteshie in contemporary Ghanaian society, highlighting the post-colonial government's continued attempts to control a drink, lifestyle, culture, and way of life whose power lay in its distance from authoritarianisms and its proximity to communalisms.

Accra, Ghana's urban capital, was a key site of Nkrumah's anti-colonial activism during Ghana's decolonization phases. Jeffrey Ahlman examines the role of South African anti-colonial activists in sparking a continental, anti-colonial dialogue, producing

\footnotetext{
${ }^{66}$ Emmanuel Akyeampong, (1996), "What's in a Drink? Class Struggle, Popular Culture and the Politics of Akpeteshie (Local Gin) in Ghana, 1930-67." The Journal of African History 37, no. 2, pp. 224, doi:10.1017/S0021853700035209.
} 
a 'Pan-African Accra', noting that South African organizations such as the ANC, NDP, PAC, ZAPU, and ZANU worked closely with Kwame Nkrumah and the Convention Peoples' Party in order to create an anti-colonial policy and discourse. In the analysis, Ahlman uncovers a crucial intersection between colonial experiences in South Africa, Ghana, and Kenya: settler conquest of indigenous lands and the prioritization of settler political interests over the political interests of the colonized. Additionally, Ahlman records the journey of South African activist Alfred Hutchinson, from Johannesburg to Accra, exploring the political circumstances which lay before the Ghanaian Independence Movement: mid-century African nationalism, the Cold War, and settler politics.

"While in Accra, these activists and would-be Freedom Fighters set out to define the direction, institutions, and ambitions of an independent Africa, debating along the way issues ranging from the role of violence in the African anti-colonial struggle to questions over the threats posed by neo-colonial and Cold War influences in a decolonizing continent". ${ }^{67}$

Ahlman observes a radical, anti-colonial discourse taking place in Accra, which argued the use of violent and non-violent political means in accomplishing de-colonization. Finally, Ahlman describes how the massacre at Sharpeville, occurring on March 21, 1960, served as an event which shifted and radicalized Nkrumah's views on South African conflict, as well as the advancing mechanisms of colonial settlers in West Africa. Ahlman's work usefully ties together the socio-political circumstances which served as precursors to the Mau Mau Uprising, the Ghanaian Independence Movement, and South African anti-colonial activism.

${ }^{67}$ Jeffrey Ahlman, (2011), "Road to Ghana: Nkrumah, Southern Africa and the Eclipse of a Decolonizing Africa." Kronos, (37), pp. 24 
In "We Shall Be Outspoken”, Emmanuel Asiedu-Acquah examines student political activism in Ghana during the 1950s and 60s ${ }^{68}$ Asideu-Acquah observes the political activism of Ghanaian university students, contextualizing their positions within developments in the Global South during the period. Asideu-Acquah argues that while students who performed anti-government political activism in the 1960s shared Nkrumah's views on neo-colonialism and its consequences to a post-colonial Ghana, they detested his effort to restrict dissenting political voices and social commentary. AsideuAcquah references Ghana's debate on national development in the terrain of the state and public universities, depicting confrontations between the Convention People's Party and members of higher education who opposed the state as parallels to broader tensions about the role and function of authoritarianism in Ghana's politics. Asideu-Acquad's discussion of the protest of Ghanaian university students locates the youth and young adult populations at the center of processes of knowledge production who defy the authoritarianism of the ruling powers of post-colonial Ghana: Kwame Nkrumah and the Convention People's Party.

Still, the independence movement of anti-colonialists in Ghana is captivating as a non-violent political project which reached success with greater political resolve and increased speed compared to other independence movements on the continent. The benefits yielded to an independent Ghanaian society, no longer bound by the restrictive elements of colonialism, as well as the challenges faced in establishing itself politically and economically in the 21st century, are well studied in world histories of Ghana and

${ }^{68}$ Emmanuel Asiedu-Acquah, (2019) “'We Shall Be Outspoken': Student Political Activism in Post-Independence Ghana, c.1957-1966." Journal of Asian and African Studies 54, no. 2: 169-88. doi:10.1177/0021909618806542. 
Africa. However, less popularly documented are the interpretations of Ghanaian Independence among other countries in continental Africa, especially the interpretations of non-whites and non-Africans.

This chapter observes the anti-colonial movement in Ghana for independence as reported by the Indian Opinion, illuminating resonances between the racial injustices experienced by non-European South Africans under apartheid and Ghanaians under colonial rule. The chapter will also juxtapose scholarly, historical commentary upon colonialism in Ghana with the particular emphases of the reporting of colonialism by Indian Opinion, in order to reveal the similarities and differences in how it's South African Indian readers were interpreting colonialism and anti-colonialism in Kenya and Ghana, from 1950-1960.

\section{Social Context of the Ghanaian Independence Movement}

1950 and 1951 characterized a relatively quiet reporting period on Ghanaian and Gold Coast independence movements within the Indian Opinion, which was expected given that Ghana did not receive independence until March 6, 1957, and did not contain an Indian diaspora which would warrant a uniquely designated section, such as the 'Kenya Letter'. Still, a select few articles can be interrogated and interpreted in order to understand how South African Indians interpreted the social context of the anti-colonial movement of the Convention People's Party (CPP) in Ghana's path to independence. These articles, encompassed under a section called "Things in General", served to narrate events of anti-colonial protest in West, East, and South Africa, as well as East and South Asia. Thus, to a South-African Indian reader of the Indian Opinion, the social context of 
the Ghanaian Independence Movement is framed through events of the anti-colonial protest, and the socio-political conditions which necessitate and/or bring about events of protest.

Indian Opinion begins its coverage by narrating a stadium-wide chant of "Lead, Kindly, Light" which took place in February 1950, inside a popular sports arena in Accra. Indian Opinion emphasizes the chant as a protest form which would spur both colonial responses and in turn, the formation of a larger civil disobedience campaign in Ghana. In regards to the cycle of colonial response and civil disobedience, the article reports: "This was the evidence of Native policemen at the trial of nine Natives charged with inciting an illegal strike. They said the meeting was led in a prayer which invoked God into their midst". ${ }^{69}$ The religious formation of the chant, which may be implied in the spiritual phrasing of "Lead, Kindly, Light", draws from a hymn written by John Henry Newman in June of 1833. Indian Opinion interprets the protest event both as a performance of West African Christianity and as a scene which highlights colonial discomforts with protest.

Indian Opinion emphasizes the manner in which the protest event drew the attention of police, and envisions how the response of the police characterizes colonial attitudes towards the resentments of the urban working class. Speaking to the religious impulses of the hymn, Gandhi wrote in a letter to Vinoba Bhave: "In my daily prayers I earnestly pray to God to lead me from untruth to truth. Isn't the same idea conveyed in

\footnotetext{
${ }^{69}$ Manilal Gandhi, \& Natal Phoenix, "Gold Coast Natives Go On Strike", Indian Opinion, Feb. 3, 1950
} 
'Lead, Kindly, Light'?”. ${ }^{70}$ Emilsen, in "Gandhi and Lead, Kindly, Light”, emphasizes the centrality of the hymn in Gandhi's spiritual foundations to the satyagraha movement, illuminating similarities between the faith and faith-based philosophies of Gandhi, and anti-colonial protest actors in Ghana. Thus, in 1950, Indian Opinion focuses on the religious affirmation of the civil disobedience campaign in Ghana and illustrates a spiritual philosophy of Christian ethics. Additionally, Emilsen's essay displays call for justice within Gandhi's civil disobedience campaign that held deep relevance to the way South African Indians were interpreting the colonial situation in Ghana.

In 1951, reporting on Ghana's colonial situation continues with the publication of a native South African's perspective on Gold Coast elections. The writer, named Inkundla Ya Bantu, discusses the impact of the increased democratization brought about by Gold Coast elections, emphasizing what a democratic, and independent Gold Coast symbolizes to Africans not only in West, but also South Africa. The vivid connections drawn between the experiences of being subjected to British colonial rule in South Africa, Ghana, and India suggest that Indian Opinion was interpreting Gold Coast elections and the political advancement of Africans in the Gold Coast as central to anticolonial discourse in West Africa during the beginning of the decade. In emphasis of the connections examined, Bantu writes:

"The White Prophets told the world when India got her independence that she would make a mess of it... Today India is a leading power in the world and a stabilising influence in international affairs. The White Prophets have been proved wrong. They will be wrong again in the case of the Gold Coast". ${ }^{71}$

\footnotetext{
${ }^{70}$ Emilsen, William. "Gandhi and 'Lead, Kindly, Light'." This Immense Panorama: Studies in Honour of Eric J. Sharpe, 2008, pp. 227, doi:10.1177/1030570X9701000109

${ }^{71}$ Manilal Gandhi, \& Natal Phoenix, "S.A. Native View of Gold Coast Elections", Indian Opinion, Mar. 16, 1951
} 
Indian Opinion's publication of Bantu's perspective indicates multi-lateral commonalities between the colonial and anti-colonial experiences among Ghanaians and South Africans, which go beyond the sharing of colonial life experiences under British rule. Additionally, Indian Opinion is identifying in West Africa, as it did in East Africa, a process in which mechanisms of colonialism criminalize, marginalize, and displace the African in his/her society, aiming to prove that Africans were unfit to rule the Gold Coast. The racial constructions of the African in British Colonial rule, which predicate this particular view, lay at the heart of South African racialism during apartheid. Finally, the acknowledgment of an independent India and its constructive role in global affairs serves to connect the Indian cause for anti-colonial political advancement in South Africa with the West African cause for anti-colonial political advancement in the Gold Coast.

Indian Opinion's emphasis of the colonial situations in South Africa and Kenya completely consume its reporting in 1952 and 1953, its focus primarily on the ongoing South African Civil Disobedience campaign as well as the increased anti-colonial violence taking place during the time in Kenya. Thus, the happenings of colonialism and anti-colonialism in the Gold Coast would not be discussed again until July 1954, when a speech is published and interpreted by Lord Hemminglord, a rector at Acuimota Tromming College in the Gold Coast. Hemminglord references the "backwardness of the continent" as a reason for the subjects' own discontentment, projecting a view which blames the West African for conditions of colonialism which, in turn, 'require' colonial rule. Hemminglord's view is vigorously disputed by the final lines of the article:

"Europeans had to recognise the Native's dignity as human beings and fight the colour bar wherever it existed, the white people would have to be convinced that it was they 
who must make the sacrifice". ${ }^{72}$ Indian Opinion's report illustrates Hemminglord's position on rising discontentment among colonial subjects in Ghana, and in that illustration, explores hypocritical aspects of British colonialism. Indian Opinion also establishes a direct, anti-colonial interpretation of the event, critiquing the speech of Hemminglord and identifying colonialism in Ghana as the reason for discontentment among colonial subjects. The critique of Hemminglord's speech yields interpretations which emphasize a rejection of colonial racialism, experienced by South Africans, Kenyans, and Ghanaians, and thus, Indian Opinion's introduction of Ghana's anticolonial movements affirms the anti-colonial position of South African Indians as they view the trajectory of colonialism in Ghana and the Gold Coast.

\section{South African Indian Interpretations of Ghanaian Independence}

In 1955, coverage of the Gold Coast in Indian Opinion increases, maintaining its focus on the trajectory of colonialism in Ghana. In the publishing of a report in the newspaper entitled "True Democracy in Gold Coast", Mr. John Hatch, a commonwealth officer of the British Labour Party, narrates the optimistic beginnings of a more democratic, and to be independent Ghana:

"Every success the Gold Coast has in the establishment of a true democratic spirit is another nail in the coffin of racial intolerance and discrimination. All failures, weaknesses and unconstitutional actions strengthen the hands of those who preach that the African is an inferior being and will handicap Africans in every part of the continent from achieving equal rights". ${ }^{73}$

\footnotetext{
${ }^{72}$ Manilal Gandhi, \& Natal Phoenix, "Cause of Discontent Among Africans", Indian Opinion, Jul. 9, 1954

${ }^{73}$ Manilal Gandhi, \& Natal Phoenix, "True Democracy in Gold Coast", Indian Opinion, Jul. 22, 1955
} 
The acknowledgment, by an officer of the British Labor Party, of independence to be a rejection of colonial racialism and its consequences on the African in the Gold Coast indicated how colonial actors were viewing the political and social sustainability of the colonial regime in Ghana. This narrative emphasizes the inevitability of independence that Indian Opinion attributed to Ghana's political situation. Thus, Indian Opinion urged South African Indians to view the deepening of democracy in Ghana as a direct result of the strategic political work of Nkrumah and the CPP, rather than a result of colonial disengagement.

Later in 1955, a brief entry provided an accounting of Ghana's condemnation of Portugal and its colonial interactions in India: "The three-man Gold Coast Press delegation now touring India has expressed his country's 'strong condemnation of Portugal's unwanted and illogical existence on India's territory'. People in Gold Coast unitedly supported India's struggle to root out colonialism from the sub-continent". ${ }^{74}$ Additionally, the entry evidenced cooperation between Gold Coast anti-colonial journalists and Indian Journalists in Jamshedpur, where Mr. Heymann, editor of Ghana's Evening News, described how Africa looked to India for guidance in defeating British colonialism. Indian Opinion envisioned Africans as partners with Indians in a Global South, anti-colonial agenda. India's small gestures of cooperation during the time period included the establishment of an Africana Studies department in the University of New Delhi, still actively running today, and the advocating and resourcing of various educational projects and labor interests to 'Black' South Africans. Thus, Indian Opinion illuminated a budding anti-colonial relationship between India and Ghana, and, an

${ }^{74}$ Manilal Gandhi, \& Natal Phoenix, “News in Brief”, Indian Opinion, Dec. 16, 1955 
associated mobilization of resources aiming to promote solidarity among Africans and Indians. Further, Indian Opinion encouraged South African Indians to reflect upon their solidarity with 'Black' South Africans under the conditions of apartheid in South Africa, striving to better understand how Indians could be of better service to the anti-colonial agenda of West Africans in the Gold Coast.

In 1956, the joinder of Togoland with the Gold Coast was celebrated in bringing an expanded sense of independence to West Africa through the dismantling of a regional colonial presence in the Gold Coast. Narrating the overwhelming vote in favor of the joinder, Indian Opinion observes: "A resolution calling for the termination of the trusteeship agreement for British Togoland and approving its union with the Gold Coast, as soon as the latter becomes independent, was adopted by 59 votes to 0 , with 11 abstentions". ${ }^{75}$ Indian Opinion's reporting of the overwhelming vote captures the significance of Ghanaian independence to fellow nations of the Gold Coast, and emphasizes the lack of any serious political effort, on behalf of colonial actors, to protect the trusteeship as a mechanism of colonialism in the Gold Coast. Thus, the termination of the British Togoland is viewed and interpreted by Indian Opinion as a crumbling of the British colonial empire in the Gold Coast.

In the following issue, Ghana's independence is discussed by a conservative British politician, Mr. Lennox Boyd:

"the honour of the whole democratic experiment in Africa is at the moment in the hands of the people of the Gold Coast'... the Commons' unanimous support for the Independence Bill should help to convince them that our concern about these

\footnotetext{
${ }^{75}$ Manilal Gandhi, \& Natal Phoenix, "Gold Coast and Togoland Union Approved by Uno”, Indian Opinion, Dec. 14, 1956
} 
constitutional points is not a sign of lingering imperialism but of sympathetic concern for the success of a great experiment". ${ }^{76}$

The continued sense of inevitability in Indian Opinion's reporting on Ghana's independence and the success of its associated anti-colonial movement places the honor of a democratic and independent Ghana in its colonial subjects. Thus, Indian Opinion is acknowledging the ability of Nkrumah and the CPP to not only represent the political interests of West Africans in Ghana but also, to deepen democracy in the Gold Coast as a result of vigorous, anti-colonial resistance. Colonial rule was folding to the pressures of an anti-colonial Gold Coast, and excitement among anti-colonial South African Indians was brewing.

\section{South African Indian Perceptions of the Colonial Response to the Ghanaian Independence Movement}

In 1957, Indian Opinion publishes a headline news article entitled "Ghana on Eve of Independence”. The article mostly gives a broad description of the celebrations and festivities which took place in association with Ghana's independence, as well as the profound political and social significance of the event. However, a quote cited in the piece, from anti-apartheid activist and British missionary Father Huddleston, gives insight into the intimate level of connectedness which South African Indians felt in regards to the struggle for independence in Ghana: "I pray above all that Ghana may by her example inspire and sustain those millions of Africans now subject to the tyranny of

\footnotetext{
${ }^{76}$ Manilal Gandhi, \& Natal Phoenix, “Ghana's Independence”, Indian Opinion, Dec. 21, 1956
} 
racial oppression in their determination to achieve a like dignity and freedom". ${ }^{77}$ Similar to Indian Opinion's interpretation of struggles for independence in Kenya, the struggle for independence in Ghana is re-envisioned as one plight against European imperialism on the African continent.

This level of interconnectedness in and to anti-colonial struggle was furthered, and fashioned for a global, Pan-African meaning, in the final section of the piece, entitled "Up from Slavery", in relation to the famous work of Booker T. Washington:

"Finally, the attainment of independence by the people of Ghana gives special meaning to a phrase made famous by one of the most celebrated sons Africa has produced. If Booker [T.] Washington were alive today he probably would rejoice to see that an African nation has risen from slavery to freedom. We particularly rejoice that this is the case because we see in it a major reinforcement to the antiapartheid side on the continent and therefore one more victory against the evil doctrine that race determines a people's destiny". ${ }^{78}$

Thus, as independence was awarded to the people of Ghana, the interpretation of Ghanaian independence to South African Indians was fundamentally rooted in the notion of a shared struggle against colonialism. Indian Opinion's reporting of anti-colonial struggles during the 1950s-1960s began in rejecting South African racialism in apartheid South Africa, was maintained through its investigation of colonial rule in East Africa and Kenya, and concluded with a celebration of Gold Coast independence as a symbol of the political liberation of West Africa. Thus, South African Indians interpretation of colonialism and anti-colonialism on the continent are characterized by a transformative

${ }^{77}$ Manilal Gandhi, \& Natal Phoenix, "Ghana on Eve of Independence”, Indian Opinion, Mar. 8, 1957

${ }^{78}$ Manilal Gandhi, \& Natal Phoenix, "Ghana on Eve of Independence”, Indian Opinion, Mar. 8, 1957 
social view of freedom movements who seek to defeat racialism as a mechanism of colonialism.

Indian Opinion emphasized the manner in which Nkrumah would continue to fight racialism as a mechanism of colonialism once in office, through the establishment of a special counsel functioning to assess and defend the political interests of anticolonial Africans in South Africa. These actions would trigger the alarms of colonial actors, illustrating how Nkrumah's contestation of African racialism in South Africa would elicit various responses from colonial actors. At first, South African colonial actors attempted to be-friend Nkrumah, ignoring his substantive political efforts to protest racialism in South Africa. Indian Opinion reports: "According to the Capetown correspondent of the "Natal Mercury" Mr. Louw, Minister of External Affairs, doubts whether the Prime Minister of Ghana, Dr. Nkrumah, was correctly reported when he allegedly said that he hoped to establish a High Commission in South Africa soon" ${ }^{79} \mathrm{Mr}$. Louw, a representative of the colonial government in South Africa, acknowledges, and asserts doubt, over the possibility of Nkrumah contesting racialism in South Africa. Indian Opinion's emphasis of the reporting suggested that colonial actors were still dealing with Nkrumah's anti-colonial presence at the turn of the decade, and urged South African Indians to view Nkrumah as a fellow figure in anti-apartheid resistance. When Nkrumah decided to abstain the formation of diplomatic ties between Ghana and the colonial government of South Africa, Mr. Louw began to respond to Nkrumah with a sense of aggravation.

\footnotetext{
${ }^{79}$ Manilal Gandhi, \& Natal Phoenix, "Louw Hedges on Diplomatic Relations with Ghana”, Indian Opinion, Jan. 23, 1959
} 
Just a month later, Mr. Louw is again quoted in an Indian Opinion report, displaying an interpretation of Nkrumah and his anti-racialist ideologies as a threat to the colonial order in South Africa. To emphasize Mr. Louw's characterization of the threat which Nkrumah produced, Indian Opinion notes: “The Minister of External Affairs, Mr. Louw, has accused the Ghana Cabinet of provocation... Mr. Louw was referring in particular to a report which quoted the Ghanaian Minister of External Affairs, Mr. Kojo Botsio, as confirming that his Government had made approaches to South Africa" ${ }^{80}$ Nkrumah had directed his ministers to exchange diplomats in South Africa, sending the message to colonial actors that he was not interested in working with them. Indian Opinion interpreted Mr. Louw's coming to terms with Nkrumah as recognition of his threat to the political stability of colonialism in South Africa. Thus, Indian Opinion observed the anti-colonial presence of Nkrumah and an independent Gold Coast whose political aims to elevate the African reverberated in apartheid South Africa, and urged South African Indians to interpret the response of colonial actors in South Africa to Nkrumah as a response to a direct threat to mechanisms of colonialism inside and outside of West Africa.

\section{Gandhi's Influence: Nkrumah and the Ghanaian Independence Movement}

In Robert Addo-Fening's (1972) “Gandhi and Nkrumah: A Study of Non-violence and Non-co-operation Campaigns in India and Ghana as an Anti-Colonial Strategy", Addo-Fening surveys political work and movements led by Gandhi in South Africa and

\footnotetext{
${ }^{80}$ Manilal Gandhi, \& Natal Phoenix, "Louw Annoyed with Dr. Nkrumah", Indian Opinion, Feb. 6, 1959
} 
India, and Nkrumah in Ghana, which present methods and modes of resistance to colonialism. ${ }^{81}$ He explores satyagraha as a political philosophy articulated by Gandhi to South African Indians on behalf of legal discrimination and labor concerns, which finds its roots in a Hindu concept known as ahimsa, a religious concept emphasizing compassion and non-violence. He discusses the political accomplishments which were produced by Gandhi's employment of satyagraha, such as the mobilization of a massive Indian National Congress and the pressuring of colonial governments to withdraw various legislation.

However, Addo-Fening's optimistic presentation of satyagraha did not align, in his analysis, with the results produced by Gandhi. He states: "The question is why was satyagraha or the Civil Dis-obedience campaign so bungled by Gandhi? The answer seems to be in Gandhi's singular lack of political realism and his lack of singleness of purpose. It was this lack of realism which led him to commit the serious blunder of suspending satyagraha on two occasions, just when it seemed to be approaching a crucial stage, merely because its spirit had been violated". ${ }^{82}$ Addo-Fening argues that Gandhi's political philosophies lacked aspects of realism and purpose, which diluted the influence of satyagraha as non-violent political activism in India's Civil Disobedience campaign. Therefore, Addo-Fening ultimately finds that Gandhi's usage of satyagraha as a strategy

${ }^{81}$ Robert Addo-Fening, (1972), "Gandhi and Nkrumah: A Study of Non-violence and Non-co-operation Campaigns in India and Ghana as an Anti-Colonial Strategy." Transactions of the Historical Society of Ghana, 13(1). Retrieved from http://www.jstor.org/stable/41405805.

${ }^{82}$ Robert Addo-Fening, (1972), "Gandhi and Nkrumah: A Study of Non-violence and Non-co-operation Campaigns in India and Ghana as an Anti-Colonial Strategy." Transactions of the Historical Society of Ghana, 13(1), pp. 75 
of resistance to colonialism in South Africa was inconsistent, and only offered mixed results to evidence effectivity.

Next, Addo-Fening records the employment of satyagraha in Ghanaian nationalist independence movements. To discuss common motives which invigorated the spread of satyagraha philosophy across the African continent, Addo-Fening highlights two striking similarities between Gandhi and Nkrumah: first, a shared view of the West's science, industry, medicine, and urbanization as contemptuous and evil, and second, a shared view of colonialism as deeply embedded in racial discrimination. Nkrumah first had reservations about the non-violent program, but later he would champion its success (1957): “At first I could not understand how Gandhi's philosophy of non-violence could possibly be effective. It seemed to me to be utterly feeble and without hope of success. The solution to the colonial problem as I saw it at that time, lay in armed rebellion...After months of studying Gandhi's policy, and watching the effect it had, I began to see that, when backed by a strong political organization it could be the solution to the colonial problem". 83

Addo-Fening notes that the fifth Pan-African Congress, led by Nkrumah, formulated a campaign of civil disobedience which mirrored the approach and methods of the Indian experience with satyagraha, and later, that Nkrumah amassed a political movement under the Convention People's Party (CPP) which also produced a NonViolent Positive Action Program. During a speech given in 1949, Nkrumah confirmed the presence of Gandhi's satyagraha political philosophy within his movement when

${ }^{83}$ Kwame Nkrumah, (1957), “Ghana: an autobiography.” London, pp. 7-8 
describing his program of positive action as "the adoption of all legitimate and constitutional means by which we could attack the forces of imperialism in the country. The weapons were legitimate political agitation, newspaper, and educational campaigns and as a last resort, the constitutional application of strikes, boycotts, and noncooperation based on the principle of absolute non-violence as used by Gandhi in India". ${ }^{84}$ Nkrumah's program of political agitation would succeed in yielding great dividends for the Ghanaian people. Addo-Fening concludes by remarking that Nkrumah's political realism, and capacity for flexibility, as well as his widespread promotion of satyagraha produced great accomplishments for the political movement he dedicated himself to, and because he built his program understanding the weaknesses of Gandhi's satyagraha campaign, Nkrumah devised a program which would, even more effectively than Gandhi's, resist the system of colonialism and promote independence.

The shared usage of satyagraha as a political philosophy for non-violent resistance between Ghanaians and Indians is meaningful for analysis in this discourse as it prompts consideration, first and foremost, of a shared anti-colonial identity between Indians and Ghanaians. One explanation for this shared identity could reference the fact that Britain was the colonizer of both India and Ghana, which creates similar states of oppression. However, due to immense demographic and geographic differences, distance remains between the acute realities of oppression. What could better explain the closing of this distance, is that colonialism acted as a global enforcement of White/European superiority, and that inter-racial cooperation was an effective tactic of resistance to colonialism. This explanation also serves to close the distance between Nkrumah and

${ }^{84}$ Kwame Nkrumah, (1957), “Ghana: an autobiography.” London, pp. 111-112 
Gandhi, after all, Nkrumah was a politician, whereas Gandhi was a spiritual figure. Indeed, Addo-Fening writes: "As a saint drawn into politics by the accident of a professional visit to South Africa, Gandhi never possessed the knack of clinching a political bargain at the opportune moment. Lord Atlee found Gandhi 'a combination of saint and astute politician'. Perhaps if Gandhi had been more of a practical politician like Kwame Nkrumah and less of a saint, satyagraha might have won independence for India sooner than it did" ${ }^{85}$

While Gandhi and Nkrumah may have had astute differences in their anti-colonial approach, Nkrumah was keen to express the inspiration the Ghanaian Independence Movement received from Gandhi's satyagraha campaigns in India and South Africa. During a visit to India, at the turn of the decade, Nkrumah expressed greetings from Ghana, emphasizing the influence that India's movement for independence had on anticolonial affairs in Ghana. Emphasizing Gandhi's particular role in this anti-colonial, trans-continental relationship, the Indian Opinion reports: "Dr. Nkrumah stated that in the African people's fight for freedom they were inspired by that greatest personalityMahatma Gandhi" ${ }^{86}$ Indian Opinion interpreted Nkrumah's visit to India, including his memorialization of Gandhi, as indicative of Afro-Asian solidarity which articulated a post-colonial effort to reject the advancement of racialism in West Africa and the Gold Coast. Thus, Indian Opinion illustrated to its South African Indian readers how Gandhi's

\footnotetext{
${ }^{85}$ Robert Addo-Fening, (1972), "Gandhi and Nkrumah: A Study of Non-violence and Non-co-operation Campaigns in India and Ghana as an Anti-Colonial Strategy." Transactions of the Historical Society of Ghana, 13(1), pp. 85

${ }^{86}$ Manilal Gandhi, \& Natal Phoenix, "Africa Should Be Freed In Our Time”, Indian Opinion, Jan. 9, 1959
} 
political work inspired Afro-Asian anti-colonial solidarity, drawing the attention of the most prominent leaders among the Ghanaian Independence Movement. 


\section{CHAPTER 4}

\section{CONCLUSION}

\section{$\underline{\text { Discussion and Analysis }}$}

This project performs a comparative analysis of South African Indian Perceptions of the Kenyan and Ghanaian Independence movements during the decade of 1950-1960, emphasizing the similarities and differences among their perceptions. In observation of the similarities between the two perceptions, the study highlights how Indian Opinion urged its predominantly South African Indian readers to: 1) reconsider and recontextualize their plight against apartheid, and Kenya/Ghana's plight for national independence, as one plight against British colonialism on the African continent, 2) view colonial regimes in Ghana and Kenya as inherently unstable, and contestable to practices of democracy, during the uprising and independence movement, and 3) view manifestations of non-violent revolution, and violent uprising, as inevitable in both colonial Kenya and Ghana at the conclusion of the decade.

Emphasis of socio-political climates in Kenya and Ghana, leading up to the birth of the Mau-Mau revolution and Ghanaian Independence movement, indicate the Indian Opinion's investment in understanding how colonialism was affecting both Kenya and Ghana's Indian and African communities. Connections drawn between South African racialism and the advancing of settler interests in political councils in East, South, and West Africa is significant to highlight as it indicates the continental and global manner in which Indian Opinion perceived British colonialism. By emphasizing establishments of 
regional, colonial political councils as advancing South African racialism to East and Central Africa, Indian Opinion called into question the political relationship, defined by power and struggle, between settlers and the indigenous.

Throughout the period of revolution, Indian Opinion focused on the institutions within colonial societies who enact violent racialism upon innocent citizens in East Africa. Indian Opinion also envisioned and framed Africans as partners with on a shared, anti-colonial agenda. Indian Opinion illuminated a budding anti-colonial relationship between India and Ghana, and, an associated mobilization of resources aiming to promote solidarity among West Africans and Indians. In doing so, Indian Opinion encouraged South African Indians to reflect upon their solidarity with 'Black' South Africans under the conditions of apartheid in South Africa, striving to better understand how Indians could be of better service to the anti-colonial agenda of West Africans in the Gold Coast, and the agenda of East Africans in Kenya. Indian Opinion and its audience interpreted the Mau-Mau uprising and the Ghanaian Independence movement as responses to a violent and unstable colonial regime. Additionally, Indian Opinion viewed colonialism at the heart of the exploding political situation and its violent manifestations. Incorporation with the colonial state and participation in a system where settlers competed with indigenous populations was no longer an acceptable avenue of a political resolution in East Africa or West Africa.

Indian Opinion emphasized how the colonial response to Ghanaian and Kenyan independence was brought about by the failure of East African and West African colonial apparatus to respond to the needs of Indians and Africans in Kenya. Opposition to colonial mechanisms in Kenya and Ghana grew throughout the 1950s, and the instability 
of the distressed British colonial regime was emblematic of a diminishing of democratic rights and a free political life for colonial subjects. Therefore, Indian Opinion would present settler projects in Kenya and British colonialism in Ghana as socially and politically unstable, setting a unique precedent in which revolution could be viewed as not only internally necessary but entirely inevitable.

South African Indian Perceptions of the Kenyan and Ghanaian independence movements from 1950-1960 also produces relevant findings to the study in terms of how they differ. In recognition of these differences, the study highlights: 1) how Indian Opinion covered the presence of an Indian Diaspora in Kenya, a population which Ghana and other West African countries did not contain, 2) the different ways in which nonviolence and violence were interpreted by Indian Opinion during the independence movements and revolutions, and 3) the manner in which Indian Opinion's coverage of Satyagraha records the distinct, yet equally imperative roles of both violence and nonviolence in the success of the two movements' anti-colonial activisms.

Indian Opinion's interpretations of Ghanaian or West African independence movements would fail to necessitate a unique section of the coverage, such as the 'Kenya Letter', due to the lack of a distinct Indian diasporic presence. However, Indian Opinion interrogated and interpreted the "Things in General" world news section, in order to interpret the larger context of Ghana's path to independence. As a result, these articles served to narrate events of anti-colonial protest in West, East, and South Africa, as well as East and South Asia. Thus, to a South-African Indian reader of the Indian Opinion, the social context of the Ghanaian Independence Movement is framed through events of anticolonial protest, and the socio-political conditions which necessitate and/or bring about 
events of protest as relevant to West Africans, whereas the social context of the MauMau was invested in understanding how colonialism affected both Kenyan Indian and African communities. In this manner, the coverage of the Mau-Mau uprising would have sparked a more participatory discussion for South African Indians, whereas the coverage of the Ghanaian independence movement felt more exploratory.

Indian Opinion articulated support and solidarity with the Kenyan independence movement from the perspective of an Indian Diaspora in continental Africa, and later, critiqued the very same views of those within the diaspora for their moral apprehension on supporting anti-colonial violence in the case of the Mau-Mau. In the case of Ghana and the Gold Coast, Indian Opinion interpreted the movements as overtly non-violent, and more similar to Gandhi's satyagraha campaign in South Africa. Support of the MauMau by the Indian Opinion reflected a significant understanding of what it meant to be an African in colonial Kenya as an Indian living in apartheid South Africa, it meant understanding the structures and mechanisms which propelled racialism to its greatest colonial heights across the continent, and finally, it meant acknowledging the formal political presence necessary to resist such an apparatus. As the revolution grew on, Indian Opinion emphasized the fact that the demanding political presence of the Mau-Mau served to exert pressure on the colonial state. Thus, while Indian Opinion was less concerned with Mau-Mau positions on violence and non-violence during the revolution, in the case of the Ghanaian Independence Movement, Indian Opinion was still invested in discussing the similarities between the satyagraha approach of the CPP and Nkrumah, and, that of Gandhi. 
Finally, Indian Opinion illustrates the cost of dismissing violent socio-political disruption as a non-viable method to protect the subjects of East-African colonialism: continued European settlement of Kikuyu lands, terroristic policing of Kikuyu families and communities, and repression of the needs and interests of the Kikuyu people. In the case of the colonial response to Ghana's independence movement, there was no cost to ignoring violent socio-political disruption as a viable anti-colonial method, as non-violent means of protest were overwhelmingly successful in Ghana. Despite Indian Opinion's coverage of the similarities between the colonial experiences of anti-colonial Indians and Africans in East Africa, Indian Opinion emphasized the notion that colonial oppression often had disparate consequences across its oppressed groups, urging South African Indians to acknowledge the shortcomings of Gandhi's philosophy of non-violence protest in producing a successful agenda of resistance to British colonialism in East Africa, while observing the accomplishments of the Gandhi's influence of non-violence on the philosophies of Ghanaian and Gold Coast Independence Movements.

\section{Summary of Findings: Gender and Race}

In summary of the study's findings, the role of gender is emphasized in the production of anti-colonial resistance, activism, and discourse in Kenya from 1950 to 1960. Leading up to the Mau-Mau uprising, Indian Opinion's coverage displayed the formation of solidarity among Asiatic and African women, in order to illustrate how various communities of women sought to better understand one another during the era of British colonialism in East Africa. During the Mau-Mau uprising, the persistent protests of Kikuyu women, on behalf of their families, and children, to the Queen of England, 
showed how women were active participants in East African anti-colonial activism. Apart from these particular narratives, however, the newspaper fails to implement substantial gender analyses in observation of colonial events and anti-colonial solidarities. As a result, the newspaper's coverage often overlooks the experiences of women in colonial East Africa and the Gold Coast. This results in the reinforcing of political hegemonies, which produce a 'male gaze' when observing Mau Mau and Ghanaian Independence activism. The 'male gaze' decentralizes the experiences of women in the two anticolonial projects and fails to locate women as key actors whom shaped Kenyan and Ghanaian movements for independence.

The role of race is highlighted in Indian Opinion's coverage of anti-colonial activisms in Kenya and Ghana from 1950-1960. The vitality of East African resistance to colonialism depended on the ability of Indian and African Kenyans to come together and resist colonialism in political solidarity. Additionally, British colonialism made imperative a common function of both the Mau Mau Uprising and the Ghanaian Independence Movement: to make seemingly isolated, and distinct experiences of colonial oppression resonate across regions and groups of people in Kenya and Ghana. In this way, the coverage of the Indian Opinion during the 1950-1950s showed how and why distinct groups of people subjected to British colonialism chose to associate as people of color, with a tendency to view their conditions under colonialism as similar and engageable across regions and cultures. 


\section{Perceptions of Violence and Non-Violence in the Mau Mau Uprising and the Ghanaian Independence Movement}

Indian Opinion's 1950-1960 coverage of British colonialism and anti-colonial activism in Kenya and Ghana displays South African Indian interpretations of the Mau Mau uprising and the Ghanaian Independence Movement as mid 20th-century African nationalisms in colonized Africa. These interpretations illuminate South African Indian perceptions of violence and non-violence, describing the role of violent resistance in the self-defense of the collective, and the role of non-violence in the leveraging of the moral status of the leaders of the independence movement. South African Indians were viewing a violent Mau Mau uprising as an anti-colonial imperative in protecting Kikuyu political leaders, land, communities, and most importantly, their children. Simultaneously, South African Indians were observing the substantial impact of non-violent resistance in the Ghanaian Independence movement and were envisioning how chants, strikes, and other forms of non-violent protest served to legitimize the political concerns of the Gold Coast working class and produce democracy. Thus, both movements, through their violent and non-violent methodologies, were interpreted by the Indian Opinion's South African readers as Pan-Africanist, satyagrahi anti-colonial agendas who prioritized the socioeconomic and political advancement of the African in Kenya and Ghana.

\section{Evaluating the Influence of Gandhi and Satyagraha on African Anti-Colonial}

\section{Activisms}

This study understands satyagraha as a philosophy which contains three principles, ahimsa, satya, and tapasya, and measures Mohandas Gandhi's influence in 
mid $20^{\text {th }}$-century African anti-colonial activisms among those principles. Colonial structures in Ghana and Kenya, whether rooted in racial oppression, economic advancement of settler interests, or the social marginalization of the African, mechanized colonial oppression through the economic and political privileging of a minority group of European settlers. The consequences of such a project were undemocratic, as they were wholly unpalatable to the majority interests of colonized Africans in Kenya and Ghana. In the same manner that colonialism was unpalatable to the colonized, the response of the colonized to colonialism were often unpalatable to the colonies and the settlers they served. Satyagraha's presence in mid-20 ${ }^{\text {th }}$-century African independence movements was no exception: its anti-colonial influence was not palatable to colonizers as it threatened to shift global sensibilities about the British East and West African colonial agenda through its ability to leverage moral positioning away from the colonizer while simultaneously rejecting mechanisms of colonial rule directly. Thus, the study's comparative analysis of Gandhi's influence in the Mau Mau Uprising and the Ghanaian Independence Movement emphasizes as much the non-violent aspect of satyagraha, as it emphasizes aspects of truth and willingness to sacrifice self-pleasure.

The prototypic understanding of satyagraha in the post-colonial era presents it solely as a non-violent resistance to colonialism. This presentation speaks to satyagraha's widespread influence in global Civil Rights Movements which achieved independence from colonialism/and or racial oppression through peaceful means, while ultimately, diminishing its revolutionary tendencies through the dismissal of satyagraha's truth and self-sacrificial aspects. Thus, in a re-examination of satyagraha which re-asserts the equivalence of three principles in the producing of an effective anti-colonial agenda, the 
analysis further shows how the contemporary iconization of Gandhi's political philosophy by previous colonizers and/or purveyors of racial injustice, such as Britain, ${ }^{87}$ France, ${ }^{88}$ and the U.S,${ }^{89}$ in a neo-globalist era which advocates political liberalisms as democratic agendas for gradual social and political change, could also be viewed as a diminishing of satyagraha's revolutionary ideological influences. Contemporary critiques of Gandhi's role as an anti-colonial actor reveal how racial antagonisms and misunderstandings remained at the core of Gandhi's work and methodology. However, the analysis as presented by this study emphasizes the manner in which South African Indians readers of the Indian Opinion were able to craft their own vision of satyagraha which observed violent and non-violent activisms as viable forms of revolution in the face of British colonialism and endorsed the formation of multi-racial solidarity in resisiting colonialism.

87 Ishaan Tharoor, "The irony behind Britain's new Mahatma Gandhi Statue", The Washington Post, 2015, sec. WV, https://www.washingtonpost.com/news/worldviews/wp/2014/07/08/the-irony-of-britainsplanned-mahatma-gandhi-statue/?utm_term $=.9 \mathrm{~d} 21 \mathrm{f} 50 \mathrm{f} 7 \mathrm{f65}$

${ }^{88}$ D Karthikeyan, "Mahatma Gandhi's statue in France: a symbol of multiculturalism", The Hindu, 2012, sec. Madurai, https://www.thehindu.com/news/cities/Madurai/mahatma-gandhisstatue-in-france-a-symbol-of-multiculturalism/article2984457.ece

${ }^{89}$ Suman Mozumder, "150 years after his birth, Mahatma Gandhi's nonviolent ways still inspire Americans", India Abroad, 2018, sec. U.S, https://www.indiaabroad.com/us_affairs/years-after-his-birth-mahatma-gandhi-snonviolent-ways-still/article_aa96ae78-c673-11e8-9a41-f39d54baadac.html. 


\section{Future Research and Changing Trends}

Future research in the topic could expand the scope of Indian Opinion's interpretations of colonialism and anti-colonialism beyond Ghana and Kenya, investigating how Indian Opinion was interpreting anti-colonialist activities in French Guyana, Fiji, and other regions outside of continental Africa. Future research could also expand on contemporary, neo-colonial settlements in Africa, that of China, Russia, and America are discussed in the Indian Opinion. Additionally, future research could elaborate on the connection between socialism on the African continent, and its use in the anti-colonial agendas of Ghanaian and Kenyan independence movements. Finally, future research could observe and interpret conceptualizations of satyagraha as relevant to contemporary apartheid struggles, such as the fight for Palestine's sovereignity and nationhood.

During the time period of the research, 1950-1960, Mohandas Gandhi was overwhelmingly received in the international community as a vanguard activist who preached non-violent political action and achieved independence from colonial rule for India in the practice of political non-violence. Today, Gandhi's influence in South Africa has been explored and investigated, and in those thorough investigations, the nuances of Gandhi's racial, social, and political views have been revealed. These conversations are important and meaningful as they reflect the discursive ways in which anti-colonial subjects are divided, and, they emphasize the manner in which colonial oppression can produce 'oppression Olympics', a cognitive dissonance experienced when observing and engaging intersecting forms of discrimination. Still, several important lessons can be gained from the study of Gandhi's influence in the Independence movements of West and 
East Africa, as Gandhi's influence in those movements goes far beyond his personal views on race, society, and politics. Indian Opinion thus serves as an excellent source for viewing and analyzing Gandhi's influence in the continental-wide independence movements of Africa during the 1950s and 1960s, while offering the critical capacity to discern how Gandhi's influence may or could have produced short-comings in the anticolonial visions of East and West Africa. 


\section{REFERENCES}

Addo-Fening, R. (1972). "Gandhi and Nkrumah: A Study of Non-violence and Non-cooperation Campaigns in India and Ghana as an Anti-Colonial Strategy.” Transactions of the Historical Society of Ghana, 13(1). Retrieved from http://www.jstor.org/stable/41405805.

Ahlman, J. (2011). Road to Ghana: Nkrumah, Southern Africa and the Eclipse of a Decolonizing Africa. Kronos, (37), 23-40.

Akyeampong, Emmanuel. "What's in a Drink? Class Struggle, Popular Culture and the Politics of Akpeteshie (Local Gin) in Ghana, 1930-67." The Journal of African History 37, no. 2 (1996): 215-36. doi:10.1017/S0021853700035209.

Asante, M.K. Afrocentricity, African American Images, (2003).

Asiedu-Acquah, Emmanuel. “'We Shall Be Outspoken’: Student Political Activism in Post-Independence Ghana, c.1957-1966.” Journal of Asian and African Studies 54, no. 2 (March 2019): 169-88. doi:10.1177/0021909618806542.

Awad, M.E. "Non-Violent Resistance: A Strategy for the Occupied Territories." Journal of Palestine Studies 13, no. 4 (1984): 22-36. doi:10.2307/2536988.

Bhagavan Sri Sathya Sai Baba. Discourses on the Bhagavad-Gita. Andhra Pradesh, Sri Sathya Sai Books and Publications Trust, 51-52, (1988).

Bermanzohn, S.A. "Violence, Nonviolence, and the Civil Rights Movement." New Political Science, 22 (1): 31-48, (2000), doi:10.1080/073931400113503. Bondurant, J.V. Conquest of Violence, The Gandhian Philosophy of Conflict. Los 
Angeles; University of California Press, 112, (1965).

Branch, Daniel. Defeating Mau Mau, Creating Kenya : Counterinsurgency, Civil War, and Decolonization. Cambridge: Cambridge University Press, 2009.

Campbell, Chloe. Race and Empire: Eugenics in Colonial Kenya. Manchester University Press, 2007, pp. 1-214.

Desai, Ashwin and Vahed, Goolam. The South African Gandhi: Stretcher-Bearer of Empire. Stanford: Stanford University Press, 2015.

Dhupelia-Mesthrie, Uma. Gandhi's Prisoner?: The Life of Gandhi's Son Manilal. Cape Town: Kwela Books,1-419, (2005).

Elkins, Caroline. Imperial Reckoning : the Untold Story of Britain's Gulag in Kenya. New York :Henry Holt and Co., 2006.

Emilsen, William. "Gandhi and 'Lead, Kindly, Light'." This Immense Panorama: Studies in Honour of Eric J. Sharpe, 2008, pp. 227-37, doi:10.1177/1030570X9701000109.

Falola, T. Africa. Vol. 4, Carolina Academic Press, 2002, pp. 1-541.

Gandhi, Mahatma, Green, M., \& Tufts University. Gandhi in india, in his own words. Hanover, N.H.: Published for Tufts University by University Press of New England, (1987).

Gandhi, Mahatma,, Tolstoy, L., Graf,, \& Murthy, B. Mahatma gandhi and leo tolstoy letters (1st U.S. ed.). Long Beach, Calif.: Long Beach Publications, (1987).

Gandhi, M.K. Nonviolence in Peace and $\operatorname{War}\left(2^{\text {nd }}\right.$ ed.). Ahmedadad, Navijivan Trust, (1994).

Gandhi, M. M., \& Phoenix, N. (1903). “Digital Innovation- South Africa.” Indian 
Opinion, Vol. 48-58,(1-49). Retrieved from http://disa.ukzn.ac.za/indianopinion-1950-1961

Green, Nile. (2012). “Africa in Indian Ink: Urdu Articulations of Indian Settlement in East Africa." The Journal of African History, 53, pp. 131-150.

India. Ministry of Information and Broadcasting. Mahatma gandhi: His life in pictures. Delhi: Publications Division, Ministry of Information and Broadcasting, Govt. of India, (1968).

Izuakor, L. (1988). “Colonial Challenges and Administrative Response: Sir Charles Eloit and 'Native' Trusteeship in Kenya, 1901 - 1904." Transafrican Journal of History, 17, 34-49.

Heller, Patrick. "Democratic Deepening in India and South Africa." Journal of Asian and African Studies, 44(1), 2009, 123-149, DOI: 10.1177/0021909608098679.

High Commission of India in Nairobi, "India-Kenya Bilateral Relations." Nov. 2018, hcinairobi.gov.in/pages.php?id=34.

Hofmeyr, Isabel and Williams, Michelle. South Africa and India: Shaping the Global South Johannesburg: Witwatersrand University Press, 2011.

Jones, S.E. Gandhi, Portrayal of a Friend. Nashville, Abingdon Press, 82, 1948.

Karthikeyan, D. "Mahatma Gandhi's statue in France: a symbol of multiculturalism." The Hindu, 2012, sec. Mad. https://www.thehindu.com/news/cities/Madurai/mahatmagandhis-statue-in-france-a-symbol-of-multiculturalism/article2984457.ece.

Kyi, A.S. Burma and India: Some Aspects of Intellectual Life Under Colonialism. Allied Publisher, New Delhi, p 58. 
Lelyveld, J. (2011). Great soul : Mahatma gandhi and his struggle with india (1st ed.). New York: Alfred A. Knopf.

Macharia, Kinuthia and Kanyua, Maigai. The social context of the mau mau movement in Kenya (1952-1960), University Press of America, Lanham, Md, 2006

Mandela, N. "The Sacred Warrior." Time, December 31, 1999, 1-3, http://content.time.com/time/subscriber/article/0,33009,993025-3,00.html.

Morris, Aldon D. "A Retrospective on the Civil Rights Movement: Political and Intellectual Landmarks." Annual Review of Sociology25 (1999): 517-39. http://www.jstor.org/stable/223515.

Nanda, B.R. Mahatma Gandhi: A Biography. New Delhi: Allied Publishers Private Ltd. Nkrumah, K (1957). “Ghana: an autobiography.” (7-8, 111-112). London. Rosenburg, Matt. "The Berlin Conference of 1884-1885 to Divide Africa." ThoughtCo, 24 Sept. 2018, www.thoughtco.com/berlin-conference-18841885-divide-africa-1433556.

Eivind Seland, (2016), "The Periplus of the Erythraean Sea: A Network Approach," Asian Review of World Histories, 4(2), pp. 191-205

Stamp, P. (1986). Local government in kenya: Ideology and political practice, 18951974. African Studies Review, 29(4), 1-17. doi:10.2307/524004 Switzer, Donna \& Switzer, Les. The Black press in South Africa and Lesotho: A descriptive bibliographic guide to African, Coloured, and Indian newspapers, newsletters, and guides in African studies. Boston: G.K. Hall \& Co., (1979).

Tharoor, Ishaan. "The irony behind Britain's new Mahatma Gandhi Statue." The Washington Post, 2015, sec. WV, 
https://www.washingtonpost.com/news/worldviews/wp/2014/07/08/the-irony-ofbritains-planned-mahatma-gandhi-statue/?utm_term=.9d21f50f7f65.

Wendt, S. "God, Gandhi, and Guns: The African American Freedom Struggle in Tuscaloosa, Alabama, 1964-1965", The Journal of African American History, 89(1), 36-56, (2004), Retrieved from http://www.jstor.org/stable/4134045. 


\section{CURRICULUM VITA}

NAME: Alexander Ganesha Kaliannan

ADDRESS: 385 Weymouth Pl

Laguna Beach, CA 92651

DOB: $\quad$ Newport Beach, CA - December 15, 1994

EDUCATION

\& TRAINING: $\quad$ B.A, Communication Studies

Loyola Marymount University

2013-2017

AWARDS: Bishop's Spirituality Award, San Juan Capistrano, CA, 2013

Fulbright Finalist \& Alternate, 2019

PRESENTATIONS: Graduate Regional Research Conference, Louisville, KY, 2018

PUBLICATIONS: Book Review of Africa, Latin America, \& the Caribbean: The Case for Bilateral and Multilateral Support for the Jounral of Global South Studies (in progress) 